C E P R E M A P

CENTRE POUR LA RECHERCHE ECONOMIQUE ET SES APPLICATIONS

Document de travail (Docweb) $\mathrm{n}^{0} 1502$

\title{
Economic Effects of the Abolition of Serfdom: Evidence from the Russian Empire
}

\author{
Andrei Markevich
}

Ekaterina Zhuravskaya

Février 2015 


\title{
Economic Effects of the Abolition of Serfdom: Evidence from the Russian Empire
}

\begin{abstract}
We document a very large increase in agricultural productivity, peasants' living standards, and industrial development in the $19^{\text {th }}$ century Imperial Russia as a result of the abolition of serfdom. We construct a novel province-level panel dataset of development outcomes and conduct a difference-in-differences analysis relying on cross-sectional variation in the shares of serfs and over-time variation in emancipation controlling for region-specific trends. We disentangle the effects of the emancipation and the subsequent land reform and show that land reform contributed negatively to agricultural productivity in contrast to a large positive effect of the emancipation. The evidence is consistent with the increase in the power of the peasant commune as the channel of the negative effect of the land reform. The different organizational forms of serfdom were associated with different levels of nutrition of serfs and productivity. The emancipation of serfs from estates where serfs were obliged to work on the landlord's farm (corvee, barshchina) caused an increase in height of their children by 1.6 centimeters. Estates where serfs were required to make in kind payment to the landlord (quitrent, obrok) were equally productive, but, in contrast, their emancipation did not lead to rise in their height. Commitment to an implicit longer-term contract on the amount of serf obligations to landlords, practiced in some estates, made serfdom more productive.
\end{abstract}

Keywords: development, forced labor, Russian empire, serfdom

JEL Classification: N33, N35, O1

\section{Les effets économiques de l'abolition du servage: la cas de l'Empire russe}

Résumé: Nous montrons une très forte augmentation de la productivité agricole, du niveau de vie des paysans, et du développement industriel au 19ème siècle dans la Russie impériale à la suite de l'abolition du servage. Nous construisons une nouvelle base de données en panel au niveau des régions sur les résultats en termes de développement et utilisons la méthode de différence des différences en s'appuyant sur la variation en coupe transversale de la proportion de serfs et sur la variation temporelle de l'émancipation. Nous distinguons entre les effets de l'émancipation et de la réforme agraire ultérieure et montrons que la réforme agraire a contribué de manière négative à la productivité agricole contrairement à un grand effet positif de l'émancipation. Nous émettons l'hypothèse que l'effet négatif de la réforme agraire est dû au renforcement de la puissance de la commune paysanne. Les différentes formes d'organisation du servage ont été associées à différents niveaux de nutrition des serfs et de productivité. L'émancipation des serfs dans des domaines où les serfs étaient obligés de travailler sur la ferme du propriétaire (corvées, barshchina) a contribué à augmenter la taille de leurs enfants par 1,6 centimètres. Les domaines où les serfs ont été obligés à un paiement en nature au propriétaire (quitrent, obrok) étaient tout aussi productifs , mais, en revanche, leur émancipation n'a pas conduit à augmenter la taille des enfants des paysans. En cas des contrats implicites à long terme sur le montant des obligations de serfs envers les propriétaires, pratiqués dans certains domaines, le servage s’est avéré plus productif. 


\title{
Economic Effects of the Abolition of Serfdom: Evidence from the Russian Empire
}

\author{
Andrei Markevich and Ekaterina Zhuravskaya ${ }^{a}$
}

October 24, 2014

\begin{abstract}
We document a very large increase in agricultural productivity, peasants' living standards, and industrial development in the $19^{\text {th }}$ century Imperial Russia as a result of the abolition of serfdom. We construct a novel province-level panel dataset on development outcomes and conduct a difference-in-differences analysis relying on cross-sectional variation in the shares of serfs and over-time variation in emancipation controlling for region-specific trends. We disentangle the effects of the emancipation and the subsequent land reform and show that land reform contributed negatively to agricultural productivity in contrast to a large positive effect of the emancipation. The evidence is consistent with the increase in the power of the peasant commune being the channel of the negative effect of the land reform. Different organization of serfdom was associated with different levels of nutrition of serfs and productivity. The emancipation of serfs from the estates, where serfs were obliged to work on the landlord's farm (corvee, barshchina), caused an increase in height of their children by 1.6 centimeters. Estates, where serfs were required to make in kind payment to the landlord (quitrent, obrok), were equally productive, but, in contrast, were not associated with malnutrition of serfs. Commitment to an implicit longer-term contract on the amount of serf obligations to landlords, practiced in some estates, made serfdom more productive.
\end{abstract}

\footnotetext{
${ }^{a}$ Andrei Markevich is from the New Economic School and Hoover Institution, Stanford University. Ekaterina Zhuravskaya is from the Paris School of Economics (EHESS). The corresponding author is Andrei Markevich: Hoover Institution, Stanford University, Stanford, CA 94305, US. Email: ammarkevich@gmail.com. We would like to thank Greg Clark, Paul Dower, Amanda Greg, Paul Gregory, Avner Greif, Sergei Guriev, Tim Guinean, Mark Harrison, Peter Lindert, Steven Nafziger, Alan Olmstead and Gavin Wright for their comments. We thank Andrei Govorun, Guli Kholmatova and Olga Pavlenko for excellent research assistance.
} 


\section{Introduction}

Over centuries forced labor was a dominant form of labor relations. Free labor market is a relatively recent phenomenon. The vast literature on economic history and long-term economic development agrees that the emergence of free contractual labor relations contributed to economic development though its effects on incentive structure of laborers and superior institutions. For example, North and Thomas (1970) argued that the rise of the Western Europe in the middle of the second millennium occurred because of early development of the institution of private property and disappearance of serfdom. More recently Engerman and Sokoloff (1997), Nunn (2008), Nunn and Wantchekon (2011) and Acemoglu et al. (2012) provided evidence on the channels: forced labor and slave trade contributed to the emergence of inferior formal and informal institutions. There is, however, fairly little systematic evidence on the effect of forced labor on agricultural productivity or industrial development in Europe. The best documented is the case of the American slavery, in which slave owners managed to design incentive schemes that minimized potential negative effects of forced labor on productivity. As demonstrated by Fogel and Engerman (1974) and Fogel (1989), in the Americas of the 17th-19th century, cotton, sugar cane, and tobacco production on large farms with slaves was more productive than on farms that relied on free labor. The main reasons for this difference were the economies of scale and specialization, better realized in slave farms due to the state-of-the-art technology available at that time.

This paper is the first to estimate empirically the effects of the abolition of serfdom on agricultural productivity, peasant nutrition and mortality, and industrial development in one of the three European superpowers of the 19th century, where serfdom existed in the modern times, the Russian Empire.

There is a long-lasting debate among historians about the effect of serfdom on Russia's economic development. Gerschenkron $(1962,1965)$ argued that serfdom substantially slowed down Russian economic growth; Koval'chenko (1967) shared this view and argued that serfdom was even unprofitable for nobility during its last several decades. In contrast, Moon (1996), Mironov (2010), Dennison (2006, 2011) and especially Stanziani (2014) portrayed serfdom as a dynamic institution that sustained a considerable speed of economic development because landlords guaranteed and enforced social order, accumulated resources to launch new projects when access to credit was limited, provided minimum food consumption to peasants during famines, and adopted new technologies, in contrast to free peasant communes. Hoc and Wilson (1979) and Domar and Machina (1984) documented case studies suggesting that serfdom 
remained profitable for gentry till its very end. The arguments in this debate were based primarily on sporadic anecdotal evidence.

Our paper resolves this debate by providing systematic evidence on a very large positive effect of the abolition of serfdom on all most important dimensions of economic development. The magnitude of the effect can be illustrated with a simple counterfactual exercise: Russia would have been about twice as rich by 1913, had it abolished serfdom in 1820 instead of 1861, as was considered by Alexander I and demanded by the "Dekabrists" gentry liberals. Our analysis was made possible because we assembled a new province-level panel data set that is the best source of statistics on development of Russia in the end of the 18th and throughout the 19th century.

To estimate the effects of the abolition of serfdom, we rely on geographic variation in the prevalence of serfdom across Russian provinces, an over-time variation in the emancipation of serfs, and cross-province and over-time variation in the speed, with which the land reform was implemented. Our main empirical strategy is difference-in-differences with controls for province and time fixed effects and region-specific trends. As different regions of the Imperial Russia had different development trajectories due to Russia's vast size and, thus, different climatic and soil conditions, controlling for development differential trends is essential in the estimation of the effects of the abolition of serfdom. Our data allow us to do this and to conduct important specification tests. In particular, we find no evidence of pre-trends, which could potentially bias our difference-in-differences estimates; the robustness checks indicate that the results are very robust to controlling for a large number of potential confounds.

We compare development trajectories for provinces with different shares of private serfs and formally free rural residents. Private serfs constituted $43 \%$ of rural population in the European Russia in 1858. The composition of the rural population varied a lot across provinces. For example, the share of private serfs in total population in 1858 varied from $69 \%$ in Smolenskaya province to zero in the Baltics with median province having $42 \%$ of population being private serfs, as in Tambovskaya and Kurskaya provinces. The data on the composition of rural population by province in 1858 come from Bushen (1863).

The formally free rural population consisted of state peasants and free agricultural laborers; we describe their status in detail in the historical background section. Private serfs were the property of the nobility, who had full formal usage and transfer ownership rights over their serfs, subject to maintaining minimal living standards of serfs, occasionally enforced by the state. The nobility fully determined the form and the amount of labor and in kind obligations of serfs to them. Endogenously, two main organizational types of serfdom emerged, depending on what was viewed as more profitable for nobility: corvee (barshchina) with serfs working on the 
landlords farm (the closest to the American slavery) and quitrent (obrok) with peasants cultivating personal plots and paying in kind and in cash contributions to their owner.

The abolition of serfdom in the Russian empire entailed two distinct dimensions: the emancipation, which gave personal freedom to serfs, and the subsequent land reform, which defined communal land property rights of emancipated peasants. The emancipation came in two stages: between 1816 and 1819, private serfs were liberated in the three Baltic provinces, and subsequently, the Peasant Reform of 1861 liberated private serfs throughout the empire. The emancipation transformed private serfs into free agricultural entrepreneurs. Their obligations to landlords were fixed and then completely abolished by the land reform that gradually transferred land rights to peasant communes. The land reform was implemented gradually during 1862-1881 with different speed in different provinces. There was no land reform in the Baltic provinces.

Our main results are as follows. First, we examine the effect of the abolition of serfdom on agricultural productivity. In contrast to the literature on the 19th century US slavery, we find that the abolition of serfdom resulted in a large and significant increase in grain and potato productivity (i.e., the ratio of grain yield to seed and potatoes yield to planted potatoes, our best available measures of productivity) and the use of cattle (cattle per capita). In an average province, with $42 \%$ of rural population comprised of private serfs, the abolition of serfdom led to a $10.4 \%$ increase in grain productivity, a $15 \%$ increase in potato productivity, and a $22 \%$ increase in cattle stock per capita on top of the overall development trend. This is a large effect comparable to 40 years of aggregate development: grain productivity on average was increasing by $2.5 \%$ per decade in the 19 th century Russia.

Second, we disentangle the effects of the two components of the abolition of serfdom: emancipation per se and the land reform. We find that the positive effect of the abolition of serfdom on productivity is entirely due to emancipation. Obtaining personal freedom by serfs boosted growth in agricultural productivity, whereas the land reform slowed it down, leaving the overall effect of the abolition of serfdom positive. The effect of the abolition of serfdom on productivity would have been $70 \%$ larger if the land reform did not cause the productivity slowdown. We provide evidence on the channel of influence: the land reform increased the bargaining power of the peasant commune and exacerbated its inefficiency. We show that negative effects of the land reform on productivity decreased with the land abundance, which arguably was negatively associated with the bargaining power of the peasant commune. Our findings support the Gerschenkron's (1965) conjecture that the commune was an inefficient institution. ${ }^{1}$

\footnotetext{
${ }^{1}$ We also estimate the effect of the 1866 land reform that affected state peasants. This reform also led to productivity improvements. This result is consistent with our finding on the differential effect of the land reform for
} 
Third, we estimate the differential effects of the abolition of serfdom on productivity depending on its organizational structure. The abolition of serfdom led to equal productivity gains in places with corvee and quitrent. However, large corvee farms, prevalent in the black earth provinces, benefited from the economies of scale, and the abolition of serfdom led to smaller productivity gains in these estates. We also document that in the estates, where, right after the emancipation, landlords and peasants were able to agree about the amount of peasants obligations to landlord and write them down in the form of a regulatory charter (ustavnaya gramota), the effect of the emancipation on agricultural productivity was significantly lower compared to the estates, where landlords and peasants could not agree. We interpret the ability to reach such an agreement as evidence of an implicit longer-term contract that existed prior to the abolition of serfdom between the peasants and the landlord, which became a focal point of the agreement. In estates, where the implicit contracts regulated the amount of obligations of peasants to landlord, serfdom was less inefficient compared to the estates, where landlords did not bind themselves by longer-term implicit contracts.

Forth, we show that the abolition of serfdom substantially increased living standards of former serfs. The emancipation substantially increased child nutrition (as measured by draftees' height) in estates, where serfs were obliged to work on the landlord's farm, corvee. The height of draftees increased by 1.2 centimeters on average (and by 1.6 centimeters for serfs on corvee) and the mortality decreased by 5.6 deaths per thousand people in addition to the average development trend.

Finally, we find a significant positive effect of the abolition of serfdom on the industrial development of Russia's provinces. In an average province, industrial output increased by $60 \%$ and the industrial employment more than doubled as a result of the abolition of serfdom. This is a substantial effect, especially given the consensus among historians about the adverse effect of the communal system of land tittles post-emancipation on mobility of peasants to urban areas (this system was abolished only in 1906 by Piotr Stolypin). The effect would have been even larger if the land titles were individual rather than communal.

Our findings contribute to the literature on the efficiency of forced labor and its affects on economic development. While Acemoglu et al. (2012), Nunn (2008), Dell (2010), Bertocchi and Dimicio (2014), and Miller (2009) focus on the longer-run effects of forced labor through its effects on institutional development, we address the question of the effects of the abolition of Russia's serfdom on development during the half a century following the reform. The evidence presented is consistent with the main channel, through which the abolition of serfdom had its

(former) private serfs depending on the land abundance. On average, the land plots of state peasants were about twice as large as that of the private serfs. 
positive effects, being the change in the economic incentives of peasants as a result of the emancipation. We show that, in contrast to the case of the American slavery (Fogel and Engerman 1974; Fogel 1989), serfdom in the Russian empire had a large negative effect on productivity and nutrition.

We also contribute to the recent literature on economic history of the Russian Empire that uses systematic data analysis. Prior to this paper, there were few attempts to study the effects of serfdom in Russia. The most important contribution is Nafziger (2013), who described serfdom at district (uezd, the second tier administrative division) level. He was the first to document the spatial patterns in the prevalence of different types of peasantry in the European part of the Russian empire. He also documented a significant cross-sectional correlation between the variation in the prevalence of serfdom and the long-term land inequality and human capital. Our findings of the industrial development are related to the evidence reported by Nafziger (2012) that the abolition of serfdom increased off-farm activities of former serfs. Finkel et al. (2013) estimated the effect of emancipation of Russia's serfs on peasants' rebellion and found a significant increase in protest activity by peasants after the liberation. Our results on the increase of serfs' wellbeing as a result of emancipation are consistent with the idea of Finkel et al. (2013) that peasant riots were a result of a mismatch between expectations and the realization of reform, as we document a sharp increase in the peasants' standard of living. Castaneda Dower et al. (2014) found a negative link between the peasants' unrest induced by the abolition of serfdom and subsequent political liberalization, initiated by the government. Our finding on the negative effect of the land reform and the negative effect of the peasant commune on productivity in agriculture fits well with the evidence presented by Chernina et. al. (2013) and Castaneda Dower and Markevich (2013), who show that rural-urban migration and agricultural productivity increased after the abolition of the commune by Stolypin reform of 1906.

The paper proceeds as follows: in Section 2, we provide the historical background; Section 3 presents our hypotheses; in section 4, we describe the data; Section 5 presents our empirical strategy; Section 6 reports the results. In Section 7, describe a number of robustness tests. Section 8 concludes.

\section{Historical background}

\subsection{Serfdom in Russia: an overview}

Serfdom was one of the key institutions in Russian history. It existed in its most severe form between 1649 and 1861 (i.e., 212 years). Originally Russian peasants were free and could migrate across estates. The government began to limit the right of migration in the late 16th century. The 1649 Code of Law (Sobornoye Ulozhenie) proclaimed peasants the property of their 
estates and made migration out of the estates a criminal offence. Even retroactively, the peasants who fled from their estates before 1649 were ordered to be returned. Peasants in the private estates belonging to nobility became serfs, which effectively meant that they were attached to the land and had to obey orders of their landlords. Private serfs had to carry out duties and obligations in various forms for their landlords. The landlords had (almost) full discretion over the amount and the form of these obligations. The minimal constraints on these obligations came from local customs and the state's requirement to provide minimum living standards to the peasants. ${ }^{2}$ Without landlord's special permission, serfs could not leave the estate even temporarily (for example, to work in a city). On top of the usage rights, which we just described, the landlords had full transfer rights over their serfs. In particular, landlords had the right to sell, to buy, or to lease private serfs. ${ }^{3}$ Serfs did not have property rights on the means of production. In particular, the landlords had full property rights over the land, which serfs cultivated.

As we mentioned in the introduction, the two main organizational types of serfdom were corvee [barshchina] and quitrent [obrok]. The corvee system implied that estate land was separated into two parts landlord's farm and land plots given for peasants' cultivation. Serfs paid their duties to the landlord in labor, carrying out labor at landlord's farm. In the time free from work on the landlord's farm, peasants could cultivate plots provided to them by the landlord. The landlord decided on both the magnitude of labor duties and the size of plots provided to peasants; the landlord could revise these terms at any time. Under quitrent system all arable land in an estate was allocated among peasants, who cultivated their plots and paid an annual quitrent to the landlord either in cash or in kind. ${ }^{4}$ Again it was the landlord who determined the amount of quitrent at each moment in time. A mixture of corvee and quitrent obligations was also possible.

Both corvee and quitrent systems were associated with severe incentive problems. Under corvee, peasants' effort during work on the landlord's farm was largely unobservable to the landlord as monitoring was costly. In the case of quitrent, the lack of credible commitment on the part of the landlord not to revise the size of quitrent in the future reduced peasant effort due to a ratchet effect. (The ratchet effect was a problem for corvee as well). Anecdotal evidence suggests that some landlords were able to commit to a fixed amount of quitrent, maximizing stream of payments over a longer-term horizon; however, this was not a common practice

\footnotetext{
${ }^{2}$ In the extreme cases of starvation and torcher of serfs by landlords, the state could (and sometimes did) take private estates into external management by state officials. For example, in 1849 the government operated 180 private estates because of torcher and other 88 because of wastefulness (Statisticheskie ... 1852), i.e., less than a quarter of a per cent of all estates.

${ }^{3}$ During the reign of Catherine II in the second half of 18th century, when Russian serfdom reached its apogee, the nobility held the right to sell their serfs without families, like slaves. Before and after this period serfs could be bought or sold only as a part of the estate, i.e., with their families and the land, they were attached to.

${ }^{4}$ Under both corvee and quitrent systems peasants had to carry out additional obligations to landlords, like provision of timber supply, transportation services, etc.
} 
(Dennison 2011). In addition to incentive problems of serfdom, which caused lower peasant effort in production, serfdom was associated with adverse incentives for peasants to invest in land and in their own human capital (both of which belonged to the landlord). Restricted peasant mobility also implied lower industrial development, as labor could not move to the industrial sector from agriculture.

Landlords had full control over the choice of the system - corvee vs. quitrent - and, therefore, chose what was most profitable to them. Corvee system, despite severe monitoring problem, allowed landlords to utilize economies of scale better, especially in large estates, and introduce new technological advances in agriculture (Gerschenkron 1965). Corvee was the dominant form of landlords-to-peasants relations: about one quarter of all private serfs worked solely under the quitrent system and three quarters of all peasants worked under corvee and mixed corvee-quitrent system. ${ }^{5}$ According to Litvak (1972, p. 60), these shares were stable over time (Litvak 1972, P. 60).

\subsection{Geographical variation in serfdom in the mid $19^{\text {th }}$ century}

The Russian empire was a predominantly agricultural society in the 19th century. In the middle of the century, more than ninety percent of the population of the empire lived in the rural areas (Bushen 1863). But only less than half of all peasants were privately owned serfs. In 1858 in the European part of the empire excluding Poland and Finland (i.e., the territory, for which we have data and which is portrayed on Figure 1), where about eighty percent of the total population of the empire lived, there were 22,546,732 private serfs out of 52,392,030 rural residents $(43.03 \%)$. The rest were state peasants $(40.4 \%)$, free population $(12.6 \%)$, and royal peasants $(4 \%)$.

State peasants were the second most numerous group of rural labor force. Formerly, state peasants were free landless individuals living and working on the land belonging to the state. By law, they had personal and property rights and could change their occupation and place of living. The required administrative procedure for moving was so complicated, however, that few actually did this. ${ }^{6}$ State peasants had to pay a tax (in a form of quitrent) to the state in the amount fixed by the law in return for the ability to cultivate the land. The magnitude of the quitrent as well as the actual agricultural activities allowed on the land were regulated by a special ministry and were changed only rarely (three times in the 18th and four times in the 19th century).

\footnotetext{
5 The share of private serfs under the mixed corvee-quitrent system was about twenty per cent in the "black earth" region (Litvak 1972, p. 56). Outside this region, the prevalence of the mixed system is unknown.

${ }^{6}$ Note that the state peasants were free only relative to serfs, particularly, in the $18^{\text {th }}$ century, as we describe below, until 1801, the tsars often granted state lands with state peasants on these lands to nobility as private estates in exchange for military service; in that case, state peasants acquired the status of private serfs. In addition, state peasants were subject to several other administrative restrictions, which were largely removed by the first quarter of 19th century (Crisp 1976). The state peasants described themselves in the following way in the $18^{\text {th }}$ century: "we are not free, we belong to the state" (Crisp 1976 p. 76).
} 
Historians agree that, on average, living standards of state peasants were higher, individual land plots were larger, and system of quitrent was more transparent than that of private serfs (Druzhinin 1958). In the late 1830s - 1840s the government conducted a so-called Kiselev's reform, which guaranteed a minimal-size land plot to each state-peasant household and improved administration of the state-peasant villages. If the population in these villages grew bypassing the minimum required land-household ratio, the state initiated migration programs to virgin lands in the South and East of the empire (Druzhinin 1958; Crisp 1976).

The third group - free agricultural laborers with or without land titles $(12.6 \%$ of rural population in 1858). This group consisted of Cossacks with commune land title, colonists, who cultivated land under various land arrangements, local non-Russians in Astrakhan and Bessarabiya provinces without land. In addition, after the 1819 reform, the largely landless peasants in three Baltic provinces became free laborers.

Royal (“appanage," udel'nye) peasants constituted another, much less numerous, group of peasantry. Formerly, royal peasants were private serfs belonging to the royal family on quitrent. They were managed by a special ministry (Department of Appanages) and got emancipated in 1859. In our regression analysis, we always control for the presence of royal peasants.

The composition of rural population and, in particular, the share of private serfs substantially varied across provinces because of the history of the territorial expansion of the Russian state (Nafziger 2013). Figures 2 and 3 present shares of private serfs and state peasants across the European provinces of the empire in 1858. These figures demonstrate that private serfs were more prevalent in the "old" regions of the empire that were closer to Moscow, whereas state peasants were more numerous in the outskirts of the empire. Figure A1 in appendix demonstrates a strong negative correlation between the share of private serfs and the distance to Moscow. The reason for this spatial pattern was that the introduction of serfdom in Russia was closely connected to the construction of the army. In the $16^{\text {th }}$ and $17^{\text {th }}$ centuries, being short of cash, the government gave out state lands with peasants to gentry in return for their military service. The government transferred lands to gentry more often in regions close to the capital, Moscow, because of two reasons: (1) gentry had to be mobilized to the capital quickly in case of a war; (2) government had more authority nearby the capital to enforce serfdom (Semevskij 1881, p. 29-30). Over time due to a short supply of remaining state lands in the old regions and the colonization of new territories, the state transferred more distant lands with peasants to gentry as well. The government continued such practice of transfers during the whole of the $18^{\text {th }}$ century (even after the 1704 military reform, which introduced regular army instead of the estate one). In particular, Catherine II (1762-1796) transferred 800 thousand state 
peasants to private owners; Pavel I (1796-1801) transferred another 400 thousand (Semevskij 1881, 1901, 1906). Only Alexander I, who assumed the throne in 1801, ordered to stop the practice of transfers of state lands into private ownership of nobles. ${ }^{7}$ Gentry also often captured state lands (with state peasants on them), eventually legalizing their titles. Using 1684-1686 census data, Vodarskij (1988) estimates that gentry captured 36 percent of all privately owned estates. This share was higher in the "black earth" region where soil was more fertile; the state was too weak to enforce state ownership of these lands. Tsars only managed to keep the very best lands in their own personal ownership as royal estates with "royal peasants" (Indova 1964). There was also one transfer from private ownership of lands into state ownership in the $18^{\text {th }}$ century: in 1764, church land holdings were confiscated by the state and, thus, transferred to state ownership. ${ }^{8}$

The large shares of free agricultural workers were concentrated in very special regions of Russia, as shown on Figure 4. In particular, Cossacks in Don region were free because in the $17^{\text {th }}$ century the government needed them to protect the country from the nomadic invasions from the South. The state also granted free status to local non-Russians in the low Volga region after the conquest of this region in order to avoid rebellion of the new imperial subjects. Similarly, the peasants of Bessarabia (tzaryane) were granted a special status of (relatively) free rural population after the conquest of this province in $1811 .^{9}$ In addition, over the course of the $18^{\text {th }}$ and the first half of $19^{\text {th }}$ century the government invited colonists from Europe to settle in virgin land of the empire in the South and the East.

Overall, the distribution of private serfs, state peasants and free laborers across provinces in Russia became relatively stable by 1801 . It persisted until the Peasant Reform of 1861, which emancipated private serfs, with the exception of the three Baltic provinces, where private serfs were emancipated in 1816-1819.

\subsection{The abolition of serfdom: the emancipation and the land reform}

As mentioned above, the abolition of serfdom in Russia consisted of two conceptually different reforms: the emancipation and the land reform. The 1861 manifesto both granted personal freedom to former serfs and outlined the rules of the subsequent land reform.

According to the 1861 law, private serfs were granted freedom instantaneously and free of charge. The law concerned all the European provinces of Russian empire with the exception of three Baltic provinces, where private serfs were emancipated forty years earlier. Peasants'

\footnotetext{
${ }^{7}$ Alexander I and his successor Nicolas I, however, practiced exchanges of state peasants in some provinces for similar number royal peasants in the other to locate royal peasants more compactly (Nifontov 1974 P. 100; Crisp 1976).

${ }^{8}$ These lands were not transferred afterwards to gentry in order to avoid conflict with the church (Semevsky 1906).

9 "Tsaryane" were formally free. They could move between landlords' estates; they cultivated land in return for an obligation (Antsupov 1978).
} 
obligations to landlords were fixed. Landlords lost the right to sell, buy, lease, to punish or to imprison peasants. Peasants were also granted a set of civil rights, including the right to marry without anybody's permission, to buy, sell and to lease property, to sign contracts, trade, to launch own business, and to represent themselves in court (Sofronenko 1954). As a result of the emancipation, peasants became full owners of their labor and human capital.

With the emancipation, former private serfs got an obligation to buy out the land from the landlord in the future, i.e., participate in the land reform. ${ }^{10}$ The landlord and the peasant commune had to negotiate on precise terms of the buyout operation, namely the amount of land, the price, and the timing. If the landlord and the peasants could not reach an agreement, the law prescribed the terms of the fallback deal. The rules varied across regions. For example, terms of the fallback option were less favorable for gentry in the western provinces (for instance, the Right-bank Ukraine, Byelorussia and Lithonia) and the time window allowed for the implementation of the land reform was smaller. The land reform was completed when the peasants got communal property rights title on their land. This happened with varying speed in different provinces, but by 1882 the land reform was fully completed in all provinces. In western provinces the legislation prescribed peasants and landlords to start buyout operation in $1863 .{ }^{11}$

The negations between the peasants and the landlord proceeded in two stages. During the first two years after the emancipation (until 1863) the landlord and the peasants had to agree on the terms of the regulatory charter (ustavnaya gramota) that fixed the land plots in peasants' use and the obligations they had to performed in exchange of the use of this land during the transition period before the actual start of the buyout operation. ${ }^{12}$ Once the charter was produced, the buyout operation could be initiated either by mutual agreement between the landlord and the peasants, or at a request of either the landlord or the peasants under the terms, specified by the law. The start of the buyout operation marked the second and the final stage of the land reform, i.e., the transfer of the communal land ownership title to peasants in exchange for the obligatory

\footnotetext{
${ }^{10}$ The law explicitly prohibited peasants from quitting without the buyout of land during the first nine years after the emancipation. After 1870, in order to quit without buying the land, peasants had to satisfy a number of restrictive conditions. In practice, less than one per cent of peasants chose quitting without the buyout of land (Litvak 1972).

${ }^{11}$ Initially, the rules were similar throughout the empire. The change in the rules was caused by the 1863 Polish rebellion. The government introduced pro-peasant changes for political reasons. The vast majority of former serfs were Ukrainians or Byelorussians in these regions, whereas landlords were Polish. The new legislation for the western provinces required no land cuts and reduces redemption payments for peasants.

${ }^{12}$ Before the regulatory charter was produced, peasants had to continue to carry out their obligations, as they existed before the emancipation; but the law limited their amount. Limitations were stricter for the corvee system. In particular, the emancipation decree restricted the list of activities that peasants had to perform for their landlords and regulated the number of corvee days. The new maximum number of corvee days per week was smaller than the average number before the emancipation. According to Litvak (1972 p. 321), the law decreased peasants' oblgations under the corvee system up to two thirds of what they used to be on average. As a result, many landlords chose to transfer their peasants from corvee to quitrent (Zajonckovskij 1968 P. 244) between 1861 and 1863. The 1861 law prohibited transfers of peasants from quitrent to corvee.
} 
redemption of the value of the land and the cessation of any 'temporal' obligations of peasants to the landlord.

At the first stage, the landlord was supposed to produce a draft of the charter, which peasants could agree to sign or refuse to sign. Some (but far from all) landlords were able to commit not to revise their peasants' obligations under serfdom; in this case, the landlord and the peasants considered the level of obligations as an implicit long-term contract. If such implicit contract existed and the charter followed closely its terms, the agreement between the peasants and the landlord was easier to reach. The charter had to be authorized by a local official (mirovoj posrednik), and in the case of no agreement, the local official had to produce the fallback document on his own following the law. About one half of all former private serfs signed the regulatory charters following a peaceful agreement with the landlord (Zajonckovskij 1968). The law defined the maximum and minimum amount of land that peasants could get as a result of the land reform and outlined peasants' obligations per each unit of land. ${ }^{13}$ If peasants cultivated more land before the emancipation than reform legal maximum stipulated, the landlord had to cut both their plots and obligations. If peasants had less land than the legal minimum, the law prescribed the landlord to increase their plots (Sofronenko 1954). ${ }^{14}$ In practice the land cuts were more widespread than the land extensions. After the emancipation the land became the main asset of the landlords and they tried to keep as much land in their possession as possible. According to calculations by Soviet historians, peasants lost up to one third of all peasant prereform land as a result of the first stage of the land reform (Litvak 1974; Zajonckovskij 1968).

At the second final stage the charter determined maximum amount of land that peasants could buy out. ${ }^{15}$ The land price was determined as capitalized quitrent (or corvee equivalent) fixed in the charter (Sofronenko 1954). Peasants paid twenty per cent of the land price and the state provided a loan for the other eighty percent of the value of the land. Peasants had to repay this loan to the state during the next 49 years. On average the annual redemption burden was not higher than previous quitrent or corvee (Gerschenkron 1965 p. 741).

An initiation of the buyout operation either by peasants or the landlord without a mutual agreement implied some losses for the initiator. If peasants launched the buyout operation, they

\footnotetext{
${ }^{13}$ The maximum and the minimum varied across provinces. They were equal to about 3 and 7 desyatinas per male in Russians non-"black earth" regions and to about 2 and 6 desyatinas in the black earth regions. (Desyatina is a measure of area: 1 desiatina $=117.6$ sq. feet.) Step' provinces represented an exception, where the law determined the precise size of the peasant plot.

${ }^{14}$ The law also guaranteed the landlord a minimum of land that he or she could keep in his or her possession even if peasants got less land than the legal minimum prescribed. The landlords' minimum also varied across provinces; it ranged from one third to one half of the total size of the estate. Landlords of estates with less than 21 male serfs had some additional privileges (Sofronenko 1954).

${ }^{15}$ In the case of a mutual agreement, peasants could take $1 / 4$ of the maximum land plot stipulated by law without any payment to the landlord, i.e., a gifted pauper plot (darstvennij nadel). Peasants could also request a gifted pauper plot if the landlord initiated the buyout operation. About a million peasants or about 4 percent of former serfs got gifted pauper plots as a result of the land reform (Zajonckovskij 1968).
} 
could buy out only small plots around their houses in the village, but not the arable land. In addition, in that case, they did not get a loan from the government. If the landlord launched the operation, peasants did not pay their initial twenty percent of the land price. Potential losses forced both peasants and the landlord to search for mutual agreement postponing the start of the buyout operation that provided substantial source of variation in timing of the completion of the land reform. ${ }^{16}$ Fifteen percent of former serfs postponed the buyout operation till 1881, when a new law prescribed an obligatory start of the buyout operation for all peasants who had not yet done so.

The buyout operation transferred land titles from the landlord to the peasant commune. Individual peasant households did not get individual property rights. The fact that the commune became the landowner officially strengthened the institution of the commune, whose power was previously counterbalanced by the landlord's authority. ${ }^{17}$ Gerschenkron (1965 pp. 744-5) argued that the commune and "the institutional framework, within which the peasants were placed [after the abolition of serfdom], militated directly against any improvements in this [economic efficiency] respect." Communal ownership has several important costs. First, it limited peasants' incentives to invest in land after the emancipation. This incentive problem was particularly harsh in the widespread "repartition" communes, which reallocated individual plots between households periodically. ${ }^{18}$ Second, the commune regulated production decisions of individual household, which constrained the adaptation of new technologies. Finally, the commune restricted mobility, as peasants had to ask permission from the commune to migrate. As a consequence, the institution of the commune distorted the allocation of labor. The literature (e.g., Gregory 1994 and Nafziger 2010) argues that there was a substantial variation in whether the constraints implied by the commune were actually binding in practice. The actual bargaining power of the commune varied across regions with the abundance of land, which was the main asset in collective ownership (Tukavkin 2001).

State peasants were formerly free and had the land reform in 1866, which happened momentary. The local authorities issued special commune land title documents (vladennie zapisi). These documents guaranteed peasants the land usage right in return for the fixed quitrent

\footnotetext{
${ }^{16}$ Landlords who accumulated substantial debts before the emancipation had stronger incentives to initiate the buyout operation. The state closed pre-reform credit instituions after the emancipation; and the landlords had to pay their debts to the state. About one half of all estates were used as collateral in landlord debt contracts in 1855.

${ }^{17}$ The landlord continued to counterbalance the power of the commune during the transition period. In particular, during the first eight years post-emancipation the landlord had a legal right to reallocate communal and landlord plots within the estate without peasants' consent. The landlord kept some administrative power over former serfs till 1870. It was only the buyout operation that made the commune a full owner of the peasant land removing the landlord from bargaining process completely.

${ }^{18}$ The repartition commune was a dominant form of the commune in most parts of the empire. The alternative form, the hereditary commune, in which there was individual plot ownership, was widespread only in Lithonia, Belorussia and the West-Bank Ukraine.
} 
in the next twenty years, after which quitrent was replaced by obligatory redemption payments. In western provinces redemption payments for state serfs were introduced already in 1867. Similar to the case of private serfs the land value for state peasants was estimated as capitalized quitrent for forty-six years. The land plots that state peasants got as a result of their land reform were on average twice as large as the plots of private serfs (Zajonckovskij 1968; Druzhinin 1978). In the Baltic provinces, former private serfs did not have land reform, as they did not have to buy out land. ${ }^{19}$

\section{Hypotheses}

Our aim is for test the effect of the abolition of serfdom on agricultural productivity, peasants' wellbeing and industrial development. What do we expect to find? As we discussed in the previous section, serfdom created adverse incentive for private serfs. They were not owners of their own human capital or labor; they did not have ownership rights for land they cultivated. Due to severe asymmetries of information between the principal, i.e., the owners of all these resources, namely, the gentry, and the agents, i.e., the serfs, one could expect severe distortions in production and investment decisions as well as peasant effort. The extent, to which the gentry could solve these problems by either intense monitoring or by committing to a long-term contract without falling into the ratchet effect, should determine, how inefficient serfdom was. Importantly, the emancipation of serfs changed their status from being an agent to being a principal, as they became full owner of their own human capital and labor. Thus, incentive problems - to the extent they existed under serfdom - should have been alleviated with the emancipation. However, serfdom also could have had efficiency advantages compared to postemancipation production because of the economies of scale and access to new technologies and to finance, which most probably were better realized in the large estates of the nobility compared to the small-scale entrepreneurial agricultural production by emancipated peasants. A priori, it is unclear whether the gentry were able to solve incentive problems (through commitment and monitoring) and to what extent the economies and scale and access to new technologies boosted productivity of agricultural production under serfdom. Thus, it is an empirical question. The literature on the US slavery (Fogel and Engerman 1974; Fogel 1989) suggests that the use of forced labor could be efficient under some circumstances. If the economies of scale were indeed important for agriculture in the $19^{\text {th }}$ century Russia, as many historians suggest (Anfimov 1969, Koval'chenko 1967, Litvak 1972), one should expect productivity gain from the emancipation (if any) to be smaller in provinces with larger size of the estates.

\footnotetext{
${ }^{19}$ Royal serfs had land reform in 1863. Their terms of land reform were similar to the terms of private serfs (Zajonckovskij 1968).
} 
The effects of the land reform on agricultural productivity are even more ambiguous theoretically then the effects of emancipation. On the one hand, the land reform might have increased peasants' incentives to invest into land, as they became owners of the land they cultivated, which could contribute to productivity growth. On the other hand, the land reform strengthened the inefficient institution of the commune, and in particular the repartition commune. Peasants got land under the communal rather than individual ownership, and the commune substantially restricted both the usage and the transfer land rights of individual households. It is quite possible that communal ownership of land was less efficient than landlords' ownership, because, for instance, the gentry were more flexible in adopting new technologies than the traditional peasant commune. The historical literature (Robinson 1973; Gerschenkron 1965) suggests that one should expect the effects of the land reform to differ with the type of the commune (repartition vs. hereditary) and with the actual bargaining power of the commune (Gregory 1994), which may have been, at least in part, determined by the scarcity of land.

A priori, it is also not clear whether one should expect nutrition, and therefore, peasants' (draftees') height and mortality, to be affected by the emancipation. The reason for this is that serfs were a valuable and scarce input into the production for nobility and, therefore, rational landlords should have made sure that their serfs were well fed, as nutrition directly affected peasant productivity. However, the asymmetry of information may have led to malnutrition of serfs in equilibrium, as gentry may have been concerned that peasant are hiding the proceeds of their production, which could lead to excessively high level of peasant obligations. In addition, peasants may have had lower incentives to feed children (i.e., invest in their human capital) under serfdom, as peasants' children did not belong to them, but belonged to the gentry.

Personal freedom given to serfs, in principle, should have increase mobility from rural to urban areas, where productivity, and therefore, wages were higher. This, in turn, should have had a positive effect on the development of industry. However, since peasants held collective land titles and were mutually responsible for taxes after the emancipation, an exit from the commune and migration to cities was costly (Gerschenkron 1965). Thus, whether the abolition of serfdom had a positive effect on industrial development of Russia is also a priori unclear and depends on whether peasants were ready to pay the cost of quitting the commune. In addition, gentry could have explored potential advantages of higher urban wages for peasants before the emancipation, switching them to quitrent and allowing for temporary migration to cities for seasonal work.

Overall, the effects of the abolition of serfdom are theoretically ambiguous. 


\section{Data}

We combine various published and archival sources to construct a unique province-level panel dataset on development of European provinces of the Russian empire in the $19^{\text {th }}$ century. The appendix lists all our sources in detail. Data on our outcome variables - grain and potato yields, amount of cattle, draftees height, deaths and births per 1000 inhabitants, the size of population in a province, industrial output and employment - come from the annual governor reports for the years before 1883 and the official imperial statistics for the later period. Historians agree that the quality of the late imperial statistics is rather high (Koval'chenko 1979). Nifontov (1974 pp. 35-46) provides convincing arguments that the quality of the data in governor reports is also high. ${ }^{20}$

We have different number of snapshots over time for different outcomes. The largest number of over-time observations is for grain yield: 35 snapshots. The smallest is for the industrial employment: only 3 snapshots. Table A1 in the appendix lists the years for which we have data for each of the variable used in the analysis. Some of the snapshots are the averages over a decade. By construction, these data are less volatile than the annual data. ${ }^{21}$ Occasionally, data for some provinces are missing in the historical sources; thus, the panel that we have constructed is unbalanced. To this date this is the best source of statistics on the development of the Imperial Russia in the $19^{\text {th }}$ century.

Data on the composition of rural provincial population by status, namely, the shares of private serfs, state peasants, free laborers, and royal peasants, before the 1861 reform is a crosssection; the data come from the 1858 police data (Bushen 1863). ${ }^{22}$ In addition, we constructed a proxy for the implementation of the land reform, which varies both across provinces and over time, using the redemption payments statistics, which reports the sums that peasants were supposed to pay each year in redemption by province (Vilson 1878) and the 1877 cross-section

\footnotetext{
${ }^{20}$ Accoring to Nifontov (1974), the official procedure for data collection was very detailed and careful. It required a lot of crosschecking by various local authorities. In addition, the central government carefully monitored implementation of the data collection as the data were used for potential tax redemption. It has been verified that the time-series of grain yields from the alternative sources, such as reports of the Ministry of State Property, are highly correlated with series based on the governors' reports.

${ }^{21}$ Annual figures for the agricultural output are particularly volatile because of the weather shocks. We do not have weather data. However, this is not a serious problem as the extreme historical weather shocks, in particular, droughts, usually hit a large part or even the entire European part of the Russian empire with little variation across provinces (Nifontov 1974 P. 77). Therefore, we are able to account for these shocks with time fixed effects. There is no reason to believe that the idiosyncratic weather shocks were systematically corrected with the composition of rural population in 1858 .

${ }^{22} \mathrm{We}$ also verified that our results are robust to using 1857 tax census data (Kabuzan 1971) as a source of data for the composition of the peasantry by type. The results are not reported for conciseness, but are available from the authors upon request. 1858 and 1857 figures are highly correlated. There is no consensus in the historical literature on which source is superior (Kabuzan 1971). In our baseline analysis, we rely on the 1858 police data simply because they have more observations.
} 
on the number of peasants, who had not initiated the buyout operation by that time (Vilson $1878)^{23}$

In Table 1, we report the descriptive statistics. Panel A of Table 1 summarizes data on prevalence of serfdom across provinces. Panel B presents summary statistics for the distribution of private serfs by type of obligations, estates' characteristics and the measures of land reform. As shown in the table, there were about one hundred and forty serfs per estate on average. About two thirds of all private serfs worked under corvee system; almost thirty percent were on quitrent and the rest were servants and craftsmen (dvorovye) in the estates, we refer to them as serfservants. (As figures 5 and 6 illustrate, there were more serfs on corvee in the West of the empire, whereas quitrent dominated in the Northeast, i.e., in the non-“black earth" region.)

As reported in the Panel B of Table 1, only forty three per cent of former serfs signed regulatory charters by the end of two-years period prescribed by the emancipation law in an average province. (This is our proxy for presence of implicit contracts between peasants and the landlord under serfdom.) Between 1862 and 1881, fifty nine percent of former serfs launched the land reform in an average province in an average year. The repartition commune strongly dominated in the majority of provinces after the emancipation. Average land allotment of peasant household was about fifteen desyatinas in 1877. In an average province peasants lost about six percent of land as a result of the land reform.

We summarize the development outcomes in panel $\mathrm{C}$ of Table 1. There was about one million and two hundred thousands rural citizens in a province in an average year in the $19^{\text {th }}$ century. Population grew rapidly; there were almost forty-seven births per thousand of rural population in a year and only thirty-five deaths. ${ }^{24}$ Average province was highly agricultural; there were only thirty one thousand industrial workers in a province, who produced about 18 million rubles worth of output. ${ }^{25}$ Grain was the main economic output of the empire. There are no panel data on the area under crops before 1877 or on other non-labor and labor inputs that would cover both pre- and post-emancipations periods. ${ }^{26}$ This is why we measure grain productivity as the grain yield to grain seed ratio - a measure widely used as a proxy for

\footnotetext{
${ }^{23}$ We extrapolate figures for 1878-1881 years using linear projection from 1871-1877 years. The land reform is deemed to be fully completed in all provinces by 1882 .

24 Disaggregated data on rural and urban mortality and fertility do not exist. Total fertility and mortality, nevertheless, are good proxies for rural fertility and mortality because Russia was predominantly agrarian country during the whole of the $19^{\text {th }}$ century with rural population comprising about ninety percent of total.

${ }^{25}$ Data on urbanization do not exist for this period, and therefore, we focus on industrial employment and production, only. The Russian statistics on urban population followed the legal definition of a city and counted as urban only settlements that have legal city charters. In practice, agrarian occupations dominated in many of these settlements, deemed legal "cities" by the Imperial administration (Mironov 2010).

${ }^{26}$ There are no data on labor inputs in agriculture in 19th C. Employment in agriculture is known only for 1897 population census year. Rural population figures are known only for tax census years $(1795,1811,1816,1851$, 1858) and 1897 population census years; but because of widespread cottage industry, rural population is very imprecise proxy for labor. Arable land data are available from 1877 and 1883 onwards only. There is no data on investments into land at all. Cattle are the best proxy for capital in agriculture.
} 
productivity in the Russian agriculture before the late $19^{\text {th }}$ century as well as in medieval European agriculture. Yield to seed ratio for grain was 3.95 in an average province in an average year, increasing from about 3.5 to 4.5 over the century. Potato was a more labor-intensive crop than grain with higher yield to seed ratio (about 4.4 in average). Animal husbandry had secondary importance. There was in average one head of cattle per two inhabitants in the empire. Height of a draftee was on average 164.5 centimeters. ${ }^{27}$

\section{Empirical methodology}

We use the cross-province variation in the shares of different types of peasantry and over-time and cross-province variation in the emancipation to estimate the effect of the abolition of serfdom on agricultural productivity, peasants' wellbeing, and industrial development. We run difference-in-differences regressions controlling for time and province fixed effects. As different regions are expected to have different development trajectories and the cross-province variation in the type of peasantry is non-random, it is crucial to control for both province fixed effects and development trajectories. Thus, in all specifications we control for the region-specific trends. Depending on data availability, we define regions in two different ways. For the outcomes with a large enough time dimension of the data (i.e., grain and potato productivity), we control for the liner trends specific to each of the 50 provinces. For the other outcomes, the time dimension of the panel is shorter, so we control for the linear trends, specific to each of the 15 geographic regions (rather than 50 provinces). Each of these 15 regions groups several provinces that are commonly considered as having similar development trajectories. ${ }^{28}$

In particular, our main specification is as follows:

$Y_{i t}=\alpha$ SharePrivate $_{i}$ PostEmancipation $_{i t}+\beta$ ShareState $_{i}{\text { Post } 1866_{t}}_{t}+\mathbf{X}_{\mathbf{i}} \mathbf{\prime}^{\prime} \gamma+\psi_{i}+\sigma_{t}+t \delta_{i}+\varepsilon_{i t .}$

Subscripts $i$ and $t$ index provinces and time periods. Time periods are either years or decades, depending on data availability for a particular outcome. We consider the following outcomes, denoted by $Y$ : grain yield (harvest/seed ratio), potato yield (harvest/seed ratio), cattle per capita, height of draftees in centimeters, mortality (ratio of the number of deaths to provincial population) and fertility (ratio of the number of births to provincial population), $\log$ (population), $\log ($ industrial employment), and $\log ($ industrial output). SharePrivate denotes the share of

\footnotetext{
${ }^{27}$ Rural citizens were the main source of draftees for the army. Rural population composed more than ninety per cent of total population in Russia in the middle $19^{\text {th }} \mathrm{C}$. The share of rural population varied little across provinces.

${ }^{28}$ We use the standard classification reported in imperial statistical volumes with two modifications discussed in the literature (Rossiya [Russia] in Entciklopedicheskii ... 1890-1907). First, we construct a special region for capital provinces, namely for Moscow and Saint Petersburg. Second, we separate Astrakhan' from Low Volga, adding another region. Moscow and Saint Petersburg were the only two large cities in an agrarian country. Astrakhan' was very different from other Low Volga provinces in terms of geography (desert vs. step') as well as in terms of serfdom (local non-Russian who composed majority in the province were free). We provide the precise list of the regions, provinces they are comprised of in the appendix.
} 
privately owned serfs in a province in 1858. For the three Baltic provinces, were serfdom was abolished earlier, the data indicate the number of former private serfs and state peasants. PostEmancipation denotes a dummy indicating the time after the emancipation of private serfs; it switches on in 1861 in all provinces with the exception of the three Baltic provinces, where it switches on in 1819. The interaction between the share of private serfs and the postemancipation dummy is our main variable of interest. The coefficient on this interaction $(\alpha)$ is the difference-in-differences estimator of the effect of the abolition of serfdom on the considered outcome. In order to estimate this parameter consistently, we need to control for potential confounding reforms, as well as macroeconomic shocks, unobservable characteristics of provinces and region-specific trends. In particular, we control for the land reform that affected state peasants with the interaction of the share of state peasants in 1858, denoted by ShareState, with the Post1866 dummy, which indicates the year of the land reform that affected state peasants. $\psi_{i}$ and $\sigma_{t}$ are the province and year fixed effects. $t \delta_{i}$ stands for the province- or regionspecific linear trends. We also include a number of additional controls to the list of covariates $\left(\mathbf{X}_{\mathbf{i}}\right)$. In particular, we control for the interaction of the shares of royal serfs in 1858 with the post-1859 dummy to control for the emancipation of the royal serfs; and we also control for the interaction between the land suitability and the post-1861 dummy. We follow Bertrand, Duflo, and Mullainathan (2004) and cluster error terms within each province separately before and after the emancipation. ${ }^{29}$

As the differences in the prevalence of serfdom are not random (and driven mostly by the distance to Moscow, as we described in the historical section), it is important to test for pretrends. In particular, the main identifying assumption in equation (1) is that there are no systematic differences in the trends in the outcomes of interest between provinces with different prevalence of serfdom before the emancipation. This is testable for all outcomes, for which we have sufficient number of over-time observations before the reform, namely, grain and potato productivity and draftees' height: we augment specification (1) by replacing the interaction between the share of private serfs ( SharePrivate $_{i}$ ) with post-emancipation dummy by a series of interactions of SharePrivate $_{i}$ with a number of dummies indicating pre-reform and post-reform time periods.

In order to disentangle the effect of the two components of the abolition of serfdom, namely, the emancipation, which gave personal freedom to serfs, and the subsequent land reform, which gave them communal land titles, we 1) restrict the sample to provinces which undertook the land reform (namely, all outside Baltics) and 2) include in the list of covariates several additional variables. In particular, the share of former serfs who started the buyout

\footnotetext{
${ }^{29}$ Our results are robust to using clusters by province.
} 
operation in a province in a particular year serves as a dynamic measure of land reform implementation. In order to test whether the land reform had different outcomes depending on power of the commune, we interact the measure of the land reform implementation with a proxy for land abundance. We also investigate whether the land reform varied by the commune type (reparation vs. hereditary), interacting the land reform implementation with the shares of repartitions communes in a province.

Finally, we analyze the differential effects of the abolition of serfdom for large and smallsize states of the nobility (to proxy for the economies of scale in serfdom production) by adding an interaction between SharePrivate PostEmancipation $_{i t}$ with the size of the estate and for the different organization of production within the private estates, i.e., corvee vs. quitrent by focusing on the interactions of the post-emancipation dummy with the shares of private serfs on corvee and on quitrent separately.

\section{Results}

Table 2 presents the main results on the effect of the abolition of serfdom on productivity of russian agriculture. It reports the results of the estimation of equation (1) for grain yield, potato yield, and cattle per capita. Results for the grain and potato yields are presented for specifications with province-specific trends (columns 1 and 3) and with region-specific trends (columns 2 and 4). For cattle, we can only present results with the region-specific trends, as the time dimension of the data is insufficient to estimate specification with province-specific trends.

We find evidence of a positive effect of the abolition of serfdom on agricultural productivity. The coefficients on the interactions of post-emancipation dummies with preemancipation shares of private serfs are positive and statistically significant for all measures of agricultural productivity. The magnitudes of the effects are substantial. A one standard deviation increase in the share of private serfs in a province before the emancipation (i.e., an increase of the share of private serfs in rural population by 25 percentage points) led to an increase in grain productivity by 26 percentage points (or $6.2 \%$ ) after emancipation. These are large effects, as compared to the aggregate trend in grain productivity, which, on average, increased by 10 percentage points in a decade in the $19^{\text {th }}$ century. The effect of the abolition of serfdom on potato productivity was even larger. A one standard deviation increase in the share of private serfs before the emancipation led to productivity growth by 39 percentage points or $8.8 \%$ after 1861 . In addition, the same-size increase in the share of private serfs before the reform resulted in a growth of cattle per capita by 5 percentage points in the post-reform period or by $13 \%$. For an average province with $42 \%$ of rural population comprised of private serfs, the abolition of 
serfdom led to a $10.4 \%$ increase in grain productivity, a $15 \%$ increase in potato productivity, and a $22 \%$ increase in cattle stock per capita on top of the overall development trend.

Note that the point estimate of the effect of the abolition of serfdom for grain yield and for potato yield does not change irrespective of whether we control for region- or provincespecific trends. This finding suggests that controlling for the region-specific trends is sufficient to account for diverging development trends in different areas of the vast empire. This is important, as we do not have sufficient power to control for province-specific trends for a number of our development outcomes.

In addition, the table reports estimates of the average effect of the land reform of 1866 for state peasants (i.e., the coefficients on the interactions of post-1866 reform dummies with shares of state peasants): we find no effect for potato productivity and significant positive effects of this reform on grain productivity and cattle. A one standard deviation increase in the share of state peasants (i.e., an increase by 22 percentage points) in 1858 improved grain productivity as a result of the reform by 16 percentage points or $4 \%$ and increased cattle per 6 percentage points or $18 \%$.

As described in the methodology section, we proceed to investigating possible diverging pre-trends in agricultural productivity among provinces with high and low prevalence of serfdom. For grain productivity, we estimate the coefficients at eleven interaction terms of the share of serfs in 1858 with dummies indicating five-year-period intervals, including three before the emancipation. This specification includes all baseline controls and region-specific trends. For potato yield, data are sufficient to estimate the dynamic effect for ten five-year intervals, with two before the emancipation. For this analysis, we restrict the sample to provinces, where the emancipation took place in 1861 , in order not to confuse pre-trends with the results of the abolition of serfdom in the Baltics in 1819. Figures 7 and 8 visually represent the results by plotting the coefficients on these interactions along with their confidence intervals by time periods. Columns 1 and 2 of Table A2 in the appendix present the entire regression output. For the grain productivity, the results clearly indicate the absence of pre-trends, as there are no significant effects before the emancipation reform. In addition, we find that a sharp increase in grain productivity occurred immediately after the emancipation. The coefficients are positive and significant already for the first five-year interval after the emancipation. We also see that the gain productivity continued to rise slowly for the next fifteen years after the initial jump in the first five years after the reform. The cumulative effect of the reform in the first twenty years is twice as large as in the first five years. Thus, we find only a partial support in the data on grain productivity for the claims for historians that the realization of the positive effect of emancipation was slow because of the slow institutional adjustments and associated transaction 
costs (Gerschenkron 1965, Nifontov 1974). The data do show larger effects of the abolition of serfdom in twenty years than in the first five years, consistent with the idea that realization of some productivity gains took time. However, the largest single jump in grain productivity occurred right after the emancipation. Interestingly, we find a slowdown in grain productivity (relative to the trend) in the late $19^{\text {th }}$ century. The coefficients on the interactions of the share of private serfs with five-year-period dummies after 1881 are substantially smaller (but remain positive and jointly statistically significant). We investigate the channel of this partial setback below, when we disentangle the effects of the emancipation and of the land reform for private serfs.

The results for potato productivity are slightly different. First, even though, there is no significant effect of the share of private serfs on potato productivity five to ten years before the emancipation, in the period five years before the reform, we see a large negative and significant coefficient. This is consistent with the historical account that after 1855 , both the nobility and the peasants knew that the reform is coming. This could (potentially) have led to disorganization of production and particularly so for production of potatoes, which was a relatively new crop. Second, we find more support for the conjecture made by Gerschenkron (1965) and Nifontov (1974) for the slow start in realization of the benefits of the abolition of serfdom in the case of potato productivity. It took time for the reform to affect potato productivity. The effects become positive and significant only in the 1870s. Third, just as with grain productivity, we find a setback after 1881 (when the land reform was completed), but this set back is more pronounced for potato productivity.

In Table 3, we disentangle the effects of the two components of the abolition of serfdom: the emancipation per se, which gave personal freedom to former serfs, and the subsequent land reform, on the grain productivity, the outcome, for which we have the most data. Again, we restrict our attention to the subsample of 46 provinces in the European Russia (outside the Baltics), which undertook the land reform for (former) private serfs; these are the provinces, where the emancipation took place in 1861. In the first column, for the sake of comparison, we replicate the estimation of the overall average effect of the abolition of serfdom, but on this subsample. Column 1 reports the results for the specification, identical to the one reported in Column 2 of Table 2. The results indicate that the abolition of serfdom led to a much larger productivity increase in the provinces, where emancipation took place in 1861: the coefficient on the interaction of between the share of serfs and the post-emancipation dummy is twice as large as compared to the one in the whole sample, including the Baltics. This may possibly be explained by a relatively mild condition of serfs and a more efficient production under serfdom in the Baltic provinces, and also possibly, worse conditions of their freedom. The historical 
literature (Fedorov 2000) argues that former serfs in the Baltics remained heavily dependent on the landlord even after their emancipation in many respects.

In the second column of Table 3 , in addition to the share of serfs interacted with postemancipation, we include the interaction between the share of private serfs and our measure of the implementation of the land reform, namely, the share of those (former) serfs, who started buyout operation in this province and this year among all (former) serfs into the list of covariates. In this augmented specification, the coefficient on the interaction between the share of serfs and the post-emancipation dummy estimates the effect of the emancipation (per se) and the coefficient on the interaction between the share of private serfs and the progress in land reform estimates the effect of the land reform. We find that the effect of the land reform on productivity in agriculture is negative and statistically significant, whereas the effect of the emancipation is positive (significant) and much larger than the total overall effect of the abolition of serfdom. A full implementation of the land reform (from 0 to 1 ) in an average province (outside the Baltics) led to a decrease in grain productivity by 42.3 percentage points or $10.6 \%$, following the emancipation which led to an increase in grain productivity by a 102 percentage points or $25 \%$. Thus, the land reform substantially slowed down the growth in agricultural productivity, which was boosted by the emancipation in the first place. The net effect of the abolishment of serfdom would have been up to $72 \%$ [ $=2.43 /(2.43-1.02)]$ larger, if not the setback caused by the inefficient land reform.

This result on the negative effect of the land reform is consistent with the Gerschenkron's conjecture (1965) that the land reform affected negatively the Russian agricultural development through its effect on the empowerment of the commune. It is also consistent with recent findings on the positive effect of the Stolypin reform, which allowed peasants to exit the commune (Castaneda Dower and Markevich 2013). Our results suggest that the land reform was the reason for the setback in the reform progress after 1881 - the year, when the land reform was completed. This setback is on the Figures 7 and 8, as discussed above.

In column 3 of Table 3, we start exploring the mechanism, through which the land reform had a negative effect on agricultural productivity. Our hypothesis is that the land reform increased the bargaining power of the inefficient commune. We expect this effect to be stronger in places, where land was a scarce resource, and conversely, we expect the commune to matter less (or not at all) in places, where the land was abundant. We measure the land abundance as the size of an average plot of peasant household. These data come from the first land imperial census conducted in 1877. In order to test for the effect of the importance of the commune, we add the following triple interaction term to our specification: the share of private serfs times the implementation of the land reform times the land abundance (minus its sample mean). The 
coefficient on this triple interaction term is positive and statistically significant, while the coefficient on the double interaction of the share of private serfs with the land reform remains negative and statistically significant. These results imply that while the land reform affected grain productivity negatively on average, in the relatively land abundant provinces, the effect of the land reform was positive, presumably because of less binding constraints imposed by the commune on the usage of land. Importantly, these results explain the sharp difference in the effect of the land reform for the private serfs (which was negative) and for the state peasants (which was positive, as the coefficient on the interaction between the share of state peasants and post-1866 dummy indicates). The size of the plots of state peasants was on average twice as large as plots of private serfs (Druzhinin 1978).

One could argue that our measure of land abundance - the average plot of a peasant household after the emancipation - depends on the reform implementation itself, i.e., on how much land the peasants "lost" because of the land cuts initiated by the land reform compared to how much land they cultivated under serfdom. In order to make sure that our results in column 3 are not driven by the confounding effects of land cuts, we control for the land cuts interacted with the post-emancipation dummy in column 4 . The land cuts are measured as the ratio of land that peasants lost as a result of the reform (compared to the land they cultivated under serfdom) to the amount of land they received after the abolition of serfdom. The coefficient on this interaction term is small and statistically insignificant, whereas the estimated effects of the land reform and of the land abundance remain significant. The non-result on the effect of land cuts also shows that the redistribution of land between landlords and peasants during the land reform did not significantly affect agricultural productivity.

To explore the channel through which the land reform influenced productivity further, we investigate effect of the prevalence of the repartition vs. hereditary communes. Gerschenkron (1965) and Robinson (1973) stressed that the institution of the repartition commune was particularly harmful. To the specification presented in column 2 of Table 3, we add an additional covariate: a triple interaction term between the share of private serfs, the land reform implementation, and the share of repartition communes in a province (which for 30 provinces was equal to 1 , and to other 6 was equal to 0 ). We expect the coefficient on this interaction term to be negative, as the strengthening of the repartition commune should have been more harmful than strengthening of the hereditary commune. We find no statistically significant result, but the sign of the point estimate is as expected. ${ }^{30}$

\footnotetext{
${ }^{30}$ The results for potato productivity (not reported) are broadly consistent with our findings for grain productivity, but somewhat weaker. There is one exception: a positive correlation between the land reform and the repartition commune.
} 
In Table 4, we explore the possible channels of the low productivity under serfdom. First we test for the difference between corvee and quitrent by replacing the interaction term between the share of privately owned serfs and the post-emancipation dummy with interaction terms of the shares of serfs on corvee and on quitrent with post-emancipation dummy, controlling for the interaction between the share of serfs who were servants and craftsmen (dvorovie) also postemancipation. Again, we use grain productivity as the outcome. ${ }^{31} \mathrm{We}$ find that both quitrent and corvee were equally unproductive. The difference between the effects of the abolition of serfdom for serfs on corvee and on quitrent was negligible and statistically insignificant on average, as reported in column 1 of Table 4. This is not surprising as landlords were free to choose between corvee and quitrent, which must have equalized the marginal productivity of the two in equilibrium.

In columns 2 and 3 of Table 4, we report the results of the analysis of the economies of scale under serfdom. We construct a dummy for whether an average-size estate in a province before the emancipation had larger than 100 serfs, which is about $60^{\text {th }}$ percentile of the distribution of the size of the estates across provinces. In column 2, we add a triple interaction term between the share of private serfs, the post-emancipation dummy, and the large estate dummy, without making a distinction between corvee and quitrent. In column 4, we interact the large estate dummy separately with the shares of serfs on corvee and quitrent post-emancipation. There is no evidence of the economies of scale on average if we do not distinguish between estates with corvee and quitrent (column 2). However, once we separately estimate the effect of the size of the estate with corvee and with quitrent, we find significant economies of scale for corvee system and no effect of the size of the estate for quitrent. We find that the abolition of serfdom lead to twice as large productivity improvements in the provinces with the small corvee estates than in the large corvee estates. One interpretation of this finding is that a large estate on corvee was twice as productive as a small estate on corvee under serfdom. Another interpretation, however, is that the abolition of serfdom lead to lower productivity improvements when the starting point was the large-scale corvee farm compared to small-scale corvee farm. This particular interpretation is consistent with the argument often made in the historical literature (Litvak 1974, Druzhinin 1978) about the crisis of former large corvee farms after 1861 which was caused by a combination of two factors: 1) physical punishment disappeared as a means of incentivizing peasants; and 2) large-scale landlords had problems with providing financial incentives to peasants due to shortage of liquidity and a limited access to credit markets.

\footnotetext{
${ }^{31}$ The results for potato productivity (not reported) are similar.
} 
In columns 4 of Table 4, we investigate how the presence of longer-term implicit contracts under serfdom affected the productivity of forced labor. As we describe above, we proxy for the presence of such contracts with the share of serfs, who signed regulatory charters. We find in support for the hypothesis that such implicit contracts decreased the inefficiency of serfdom production and left smaller scope for productivity improvements after the abolition of serfdom. The coefficient on the interaction term between the share of serfs, who signed regulatory charters, and post-emancipation dummy is large negative and statistically significant. The productivity increase due to the abolition of serfdom was 2.6 times larger in estates, where there were no implicit contracts prior to emancipation, compared to the estates, where such implicit contracts existed.

In the reminder of the paper, we estimate the effect of the abolition of serfdom on development outcomes beyond agricultural productivity. In this analysis, we again restrict the sample to provinces, where emancipation took place in 1861 , as we have no data before the emancipation of serfs in the Baltic provinces. Table 5 explores the effect of the abolition of serfdom on peasants' nutrition focusing on the height of draftees (i.e., a sample of 21-year-old males) in a particular year in a particular province as an outcome variable. We merge the years of the reform to the height of draftees with 21-year lag, as nutrition affects height primarily in the childhood years and estimate equation (1). In column 1 of Table 5, we compare the height of all those draftees who were born before the 1861 reform with the height of all those who were born after 1861 and relate this difference to the variation in the prevalence of serfdom. In column 2, we compare the oldest cohort, for which data are available, namely, those, who were born in 1853 and were eight years old in 1861, with all those, who were born after the 1861 emancipation. In columns 3 and 4, we repeat these exercises recognizing potential differences in gains in nutrition after the abolition of serfdom for peasants under corvee and under quitrent. We find that serfdom had a significant negative effect on child nutrition on average. This effect was very large. The abolition of serfdom in an average province led to an increase in the height of draftees by 0.5 centimeters on average (according to column 2, where we compare the draftees who lived eight first years of their lives under serfdom with those who were born after serfdom). Given that the draft affected all rural residents and not only private serfs, we can interpret the results one to one: an abolition of serfdom led to an increase in height of a (former) serf by 1.21 centimeters on average (again according to column 2). The point estimates in column 1 are understandably lower, as we compare all those who were born before 1861 to all those who were born after, but they are also large and statistically significant. In contrast, we find is no relationship between the height of draftees and reforms that affected state peasants or royal serfs. Columns 3 and 4 demonstrate that all of the negative effect of serfdom on nutrition comes from 
serfs on corvee. Serfs on quitrent were able to feed (or were more interested in feeding) their children. The abolition of serfdom in an average province on corvee increased the height of draftees by two thirds of a centimeter (according to column to 4). The serf of corvee gained 1.59 centimeters in height due to the abolition of serfdom.

To test for pre-trends and to study the dynamic effects of the abolition of serfdom on nutrition, we allow the effect of the prevalence of serfdom to vary over time, just as we did in the case of grain and potato productivity. We interact the share of private serfs with dummies for the following two-year time periods: 1855-56, 1857-58, 1859-60, 1861-62, 1863, 1865-66 and $1875 .^{32}$ Figure 9 reports the results in a graphic form and the column 3 of Table A2 in the appendix reports the regression output. The coefficients on interactions with pre-1861 period dummies are not statistically different from zero. Thus, we conclude that there is no pre-trend. In contrast, the coefficients on the interactions with post-1861 period dummies are positive and statistically significant (with the exception of the last 1875 snapshot, where the effect is imprecisely estimated). The positive effect of the emancipation on height was realized immediately after the reform and we observe an increasing diverging trend for the rest of the cohorts.

We further investigate the effects of the abolition of serfdom for the peasants' wellbeing in Table 6, by considering mortality (column 1), fertility (column 2) and population (taken in $\operatorname{logs}-$ column 3 ) as outcomes. The result are consistent with the view that the abolition of serfdom had a large positive effect on peasants' living standards and population growth, mainly through its effect on mortality. The coefficient on the interaction between the share of private serfs and the post-emancipation dummy is negative and statistically significant in the columns 1 , positive, but not statistically significant in column 2 , and positive and statistically significant in column 3. A one standard deviation increase in the share of privately owned serfs before the emancipation decreased mortality by one and a half deaths per thousand inhabitants after the emancipation. The abolition of serfdom in an average province led to a decrease in mortality by 2.35 deaths per thousand inhabitants, and as a consequence, $2.5 \%$ increase in population size. It is worth noting that these estimates assume no inter-province mobility.

Finally, in Table 7, we estimate the effect of the abolition of serfdom on industrial development. We find a positive and statistically significant effect of the abolition of serfdom onto both the industrial output and industrial employment (columns 1 and 2, respectively). A one standard deviation increase in the share of privately owned serfs before the emancipation increased industrial output by 25 percent and industrial employment by 33 percent after the abolition of serfdom. In an average province, industrial output increased by $60 \%$ and the

\footnotetext{
${ }^{32}$ We do not have data for 1865 and 1876 years.
} 
industrial employment more than doubled as a result of the abolition of serfdom. We also find a positive effect of the 1866 state peasants' land reform on the industrial output (but not the industrial employment). A one standard deviation increase in the share of state peasants in 1858 led to an increase in industrial output by 25 percent after the reform. The cumulative effect of the two reforms for an average province is large: the industrial output more than doubled (to be precise, increased by $109 \%$ ) in an average province.

\section{Sensitivity tests}

We conducted several sensitivity tests to understand how robust our findings are to measurement issue, alternative specifications and sub-samples. First, we reproduce all our estimations but with 1857 tax census data on spatial variation of serfdom as robustness check. Our main results hold; signs of the coefficients on variables of interest for 1857 data are broadly consistent with our main exercises based on 1858 data, whereas we lose statistical significance in few cases because of the decreased sample. Second, we explore whether the 1874 military reform, which abolished recruitments of peasants for lifelong military service and introduced short-term conscriptions, could explain our grain productivity results. To account for this potentially confounding reform, we add an additional interaction of the share of serfs before the emancipation with the post 1874 time dummy into our main specification. We also run a placebo test with the new interaction instead of our main variable of interest. In both cases, the results indicate that our main results are not affected by the 1874 reform. Third, we repeat the same exercises with the Kiselev's reform of the late 1830s that affected state peasants. The Kiselev's reform does not have an effect on our findings as well. Forth, we investigate whether the rapid railway expansion, which took place roughly at the same time with the abolition of serfdom had an effect on our findings. We use 1897 railway density measure to construct an interaction with the post emancipation dummy and add this measure as a control to our baseline specification. Again, the coefficient on this interaction is not statistically different from zero, while the coefficient on the interaction of share of serfs with post-1861 dummy remains positive and statistically significant. Fifth, we check whether the variation in the shares of serfs who got gifted pauper allotments as a result of emancipation land reform affect our results and find that it does not. Sixth, we try different measures of land abundance - share of arable land in a province, average size of a plot of former private serfs in 1877 . With the alternative measures, we find similar results. Finally, we repeat all our estimations, adding the interactions between postemancipation dummy and the distance to Moscow. Again, our results are robust, despite the high correlation between the distance to Moscow and the share of private serfs. 


\section{Conclusions}

We find a very large positive effect of the abolition of serfdom on agricultural productivity, peasants' living standards, and industrial development in the $19^{\text {th }}$ century Russia. The main lesson from this exercise is that serfdom substantially slowed down Russia's economic development both in agriculture and in industry. A simple counterfactual exercise yields that if serfdom were abolished in 1820, by 1913 Russia would have been about twice as rich compared to what it actually was. In 1913, according to Maddison (2007), Russia's GDP per capita was $\$ 1488$ (measured in 1990 US dollars). Our estimates suggest that the abolition of serfdom in 1820 would have implied per capita GDP in the range between $\$ 2513$ and \$2992. Thus, by 1913 Russia's would have had a level of GDP per capita comparable to Norway (\$2447) or Sweden $\left(\$ 3073\right.$ in 1913). ${ }^{33}$

The very large effects that we find on nutrition (measured by draftees' height) make the abolition of serfdom in Russia one of the most important humanitarian reforms of all times.

The data do not allow us to fully distinguish between several possible channels, through which the emancipation of serfs affected agricultural productivity. However, the evidence presented in this paper suggests that better incentives of former serfs to exert effort and to invest in their own human capital and in their children after the emancipation were the most likely mechanism, though which the abolition of serfdom affected agricultural productivity. Peasants became full owners of their labor and human capital after the emancipation; they turned into small-scale agricultural entrepreneurs. Better incentives to invest in the usage of available recourses also must have contributed to the overall effect: as we find an increase in cattle per capita due to the abolition of serfdom. Other potential channels are less likely. First, the positive effect of the emancipation on industrial employment makes it unlikely that labor input increased in agriculture due to the emancipation. Second, it is also hard to believe that substantial investments in land took place because of the communal tenure and the negative effect of the land reform on agricultural productivity. The effects of the abolition of serfdom on agricultural productivity would have been even larger, if the land reform did not transfer land ownership titles to peasant communes, but rather instituted the household-level private ownership of land. Third, as we show, land redistribution caused by the land reform did not affect agricultural

\footnotetext{
${ }^{33}$ The counterfactual exercise is as follows. We come our findings with Maddison (2007) estimate of Russian GDP per capita in 1820 and industrial structure of Russian economy in 1860 by Goldsmith (1961) and in 1913 by Markevich and Harrison (2013). Assuming that industrial structure of Russian economy was the same in 1860 and 1820, we estimate the value added in industry, agriculture and services in 1820 . Then, we momentarily increase the output in agriculture and industry according to the effects of the abolition of serfdom, that we have estimated, times 0.42 (the fraction of serfs in the country); we also extrapolate the output of the service sector, assuming that it grew with the same rate as industry. Then, we allow the economy to grow either at the rate it actually grew after the emancipation, i.e., between 1870 and 1913 (the optimistic scenario), or at its actual historical rates (the pessimistic scenario).
} 
productivity and, presumably, investments. Finally, the improvements in agricultural technologies hardly could produce the increase in productivity that large, as Russian agricultural techniques remained conservative with very few changes until the 1880s (Nifontov 1974), whereas we show that the bulk of the effect occurred immediately after the emancipation.

\section{References:}

Acemoglu, Daron; García-Jimeno, Camilo and Robinson, James A., (2012). "Finding Eldorado: Slavery and long-run development in Colombia," Journal of Comparative Economics, 40(4): 534-564.

Anfimov A.M., (1969). Krupnoe pomeshchichie khozyastvo Evropejskoj Rossii: konets 19 nachalo XX veka [Large landlord estates in European Russia in late $19^{\text {th }}-$ early $20^{\text {th }}$ Cc. ]. Moscow: Nauka.

Antsupov I.A., (1978). Agrarnie otnosheniya na yuge Bessarabii (1862-1870). [Agrarian relationship in the south of Bessarabiya, 1862-1870] Kishenev.

Bertrand Marianne, Esther Duflo, and Sendhil Mullainathan, (2004). "How Much Should We Trust Differences-in-Differences Estimates?," Quarterly Journal of Economics, 119(1): 249-275.

Bertocchi, Graziella and Arcangelo Dimicio, (2014). "Slavery, Education, and Inequality," European Economic Review, 70: 197-209.

Bushen A., (1863). Statisticheskie tablitsi Rossijskoj imperii. Nalichnoe naselenie imperii za 1858. [Statistical tables of the Russian empire. Population in 1858]. Saint-Petersburg, 1858.

Castaneda Dower Paul, Evgeny Finkel, Scott Gehlbach and Steven Nafziger, (2014). "The Substitutability of Collective Action and Representation: Evidence from Russia's Great Reforms". Mimeo.

Castaneda Dower Paul, and Andrei Markevich, (2013). "Land Tenure and Productivity in Agriculture: A Case of Stolypin Reform in Late Imperial Russia”. SSRN Working paper.

Chernina, Eugenia, Paul Castañeda Dower and Andrei Markevich, (2013). "Property Rights and Internal Migration: The Case of the Stolypin Agrarian Reform in the Russian Empire", Journal of Development Economics, forthcoming.

Crisp, Olga, (1976). The State peasants under Nicholas I. In Studies in the Russian Economy before 1914. Plymouth: Bowering press.

Dell, Melissa, (2010). “The Persistent Effects of Peru's Mining Mita." Econometrica 78(6): 1863-903.

Dennison, Tracy, (2006). “Did Serfdom Matter? Russian Rural Society 1750-1860”, Historical Research 79 (2-3): 74-89.

Dennison, Tracy, (2011). The institutional framework of Russian serfdom. Cambridge: Cambridge University Press.

Domar, Evsey and Mark Machina, (1984). "On the Profitability of Russian Serfdom." The Journal of Economic History, 44(4): 919-955.

Druzhinin N.M., (1958). Gosudarstvennie krestyane i reforma P.D. Kiseleva. [State peasants and Kiselev's reform]. Moscow, Leningrad. 
Druzhinin N.M., (1978). Russkaya derevnya na perelome. 1861-1881gg. [The Russian village during the time of great changes]. Moscow: Nauka.

Engerman Stanley L. and Kenneth L. Sokoloff, (1997). "Factor Endowments, Institutions, and Differential Paths of Growth Among New World Economies: A View from Economic Historians of the United States". Economia 3: 41-102.

Entciklopedicheskii slovar F.A. Brokgauza i I.A. Efrona [Encyclopedia published by F.A. Brokgauz and I.A. Efron]. Saint-Petersburg, 1890-1907.

Fedorov V.A., (2000). Istoriya Rossii, 1861-1917 [Russian history, 1861-1917]. Moscow: Vishaya shkola.

Finkel Evgeny, Scott Gehlbach and Tricia Olsen, (2013). "Does Reform Prevent Rebellion? Evidence from Russia's Emancipation of the Serfs". Working paper.

Fogel, Robert, (1989). Without Consent or Contract: The Rise and Fall of American Slavery.

Fogel, Robert and Stanely Engerman, (1974). Time on the Cross: The Economics of American Negro Slavery.

Gerschenkron, Alexander, (1962). Economic backwardness in historical perspective, a book of essays, Cambridge, Massachusetts: Belknap Press of Harvard University Press.

Gerschenkron, Alexander, (1965). "Agrarian Policies and Industrialisation of Russia, 18611917 " in the Cambridge Economic History of Europe. vol. 2, part 2. Cambridge.

Gregory, Paul, (1994). Before Command: The Russian Economy from Emancipation to Stalin. Princeton, NJ: Princeton University Press.

Goldsmith, Raymond W., (1961). "The Economic Growth of Tsarist Russia 1860-1913". Economic Development and Cultural Change, 9(3): 441-475.

Hoch, Steven and Wilson R. Augustine, (1979). "The Tax Censuses and the Decline of the Serf Population in Imperial Russia, 1833-1858." Slavic Review 38(3): 403-425.

Indova E.I., (1964). Dvortsovoe khozyastvo Rossii: pervaya polovina XVIII v. [Royal estate in Russia: first half of 18th C.] Moscow: Nauka.

Kabuzan V.M., (1971). Izmenenie v razmeshchenii naseleniya Rossii v 18 - pervoi polovine 19 $v v$. [Changes in population geography in 18th - first half of 19th Cc.]. Moscow.

Kessler, Gijs and Andrei Markevich, (2014), Electronic Repository of Russian Historical Statistics, 18th - 21st centuries, http://ristat.org/

Koval'chenko I.D., (1959). "Dinamika urovnya zemledelcheskogo proizvodstava v pervoi polovine 19 C." [Dynamic of agricultural output in the first half of 19th C.], History of the USSR, 1959 (1).

Koval'chenko I.D., (1967). Russkoe krepostnoe krestyanstvo v pervoj polovine 19 veka. [Russian serfs in the first half of the 19th century]. Moscow.

Koval'chenko I.D., (1979). Massovie istochniki po sotstial'no-ekonomicheskoj istorii Rossii perioda kapitalizma. [Mass sources on Russian social and economic history of the period of capitalism] Moscow: Nauka.

Litvak B.G., (1972). Russkaya derevnya v reforme 1861 goda. Chernozemnij tsentr, $1861-1895$ gg. [Russian village and 1861 reform. Black Earth center, 1861 - 1895] Moscow: Nauka.

Maddison, Angus, (2007). Contours of the World Economy 1-2030 AD. Essays in MacroEconomic History. Oxford: Oxford University Press.

Markevich, Andrei and Mark, Harrison, (2011). "Great War, Civil War and Recovery: Russia's National Income, 1913 to 1928," Journal of Economic History, 73(1): 672-703. 
Miller, Melinda, (2009). "The Shadow and Blight of Slavery: Did Free Land Have a Lasting Impact on Former Slaves?” Working paper, U.S. Naval Academy.

Mironov B.N., (2010). Blagosostoyanie naseleniya I revolutsii v imperskoj Rossii: 18 - nachalo 20 vekov. [Welfare and revolutions in imperial Russia: 18 - early 20th centuries]. Moscow.

Moon, David, (1996). "Reassessing Russian Serfdom”, European History Quarterly, 26: 483526.

Nafziger, Steven, (2010). "Peasant Communes and Factor Markets in Late Nineteenth-Century Russia," Explorations in Economic History 47(4): 381-402.

Nafziger, Steven, (2012). "Serfdom, Emancipation, and Off-Farm Labor Mobility in Tsarist Russia”. Economic History of Developing Regions, 27(1): 1-37.

Nafziger, Steven, (2013). "Serfdom, Emancipation, and Economic Development in Tsarist Russia". Working paper.

Nifontov A.S., (1974). Zernovoe proizvodstvo Rossii vo vtoroj polovine XIX veka. [Russian Grain Production in the second half of $19^{\text {th }}$ century]. Moscow: Nauka.

North, Douglass and Robert Thomas, (1970). "An Economic Theory of the Growth of the Western World," The Economic History Review, 23(1): 1-17.

Nunn, Nathan, (2008). "The Long-Term Effects of Africa's Slave Trades," The Quarterly Journal of Economics, 123(1): 139-176.

Nunn, Nathan and Leonard Wantchekon, (2011). "The Slave Trade and the Origins of Mistrust in Africa," American Economic Review, 101(7): 3221-52.

Robinson G.T., (1973, first published in 1932) Rural Russia Under the Old Regime. University of California Press;

Semevskij V.I., (1881, 1901) Krestyane v zarstvovanie Ekaterinu vtoroj [Peasants during the reign of Catherine the Second]. Vol. 1 and 2. Saint-Petersburg.

Semevskij V.I., (1906). Pozhalovanie naselennikh pomestij v tsarstvovanie Ekaterini II [Granted estates during the reign of Catherine the Second]. Saint-Petersburg.

Sofronenko K.A., (Ed.), (1954). Krestyanskaya reforma v Rossii 1861 goda. Sbornik zakonodatel'nikh aktov [Peasants reform in 1861 Russia. Laws]. Moscow: Gosyurizdat.

Stanziani, Alexander, (2014). "Russian Serfdom: A Reappraisal," Ab Imperio, 2014(2): 71-99.

Statisticheskie tablitsi sostavlennie $v$ statisticheskom otdelenii soveta MVD po svedeniyam za 1849 [Statistical tables constructed by statistical agency of the Ministry of internal affairs with data for 1849]. Saint-Petersburg, 1852.

Tukavkin V.G., (2001). Velikorusskoe krest'yanstvo i Stolypinskaya agrarnaya reforma. [Great Russian peasants and the Stolypin agrarian reform]. Moscow.

Vilson I., (1857). Obyasnenie k khozyastvennomu atlasu Evropejskoi Rossii [Explanations for economic atlas of European Russia]. 3rd edition.

Vodarskij Ya. E., (1988). Dvoryanskoe zamlevladenie v Rossii v 17 -pervoj polovine 19 vv. [Gentry landownership in Russian in 17th - first half of 19th century]. Moscow

Zajnchkovskij P.A., (1968). Otmena krepostnogo prava v Rossii [Abolishment of Serfdom in Russia]. Moscow: Nauka. 
Figure 1. European provinces of the Russian Empire

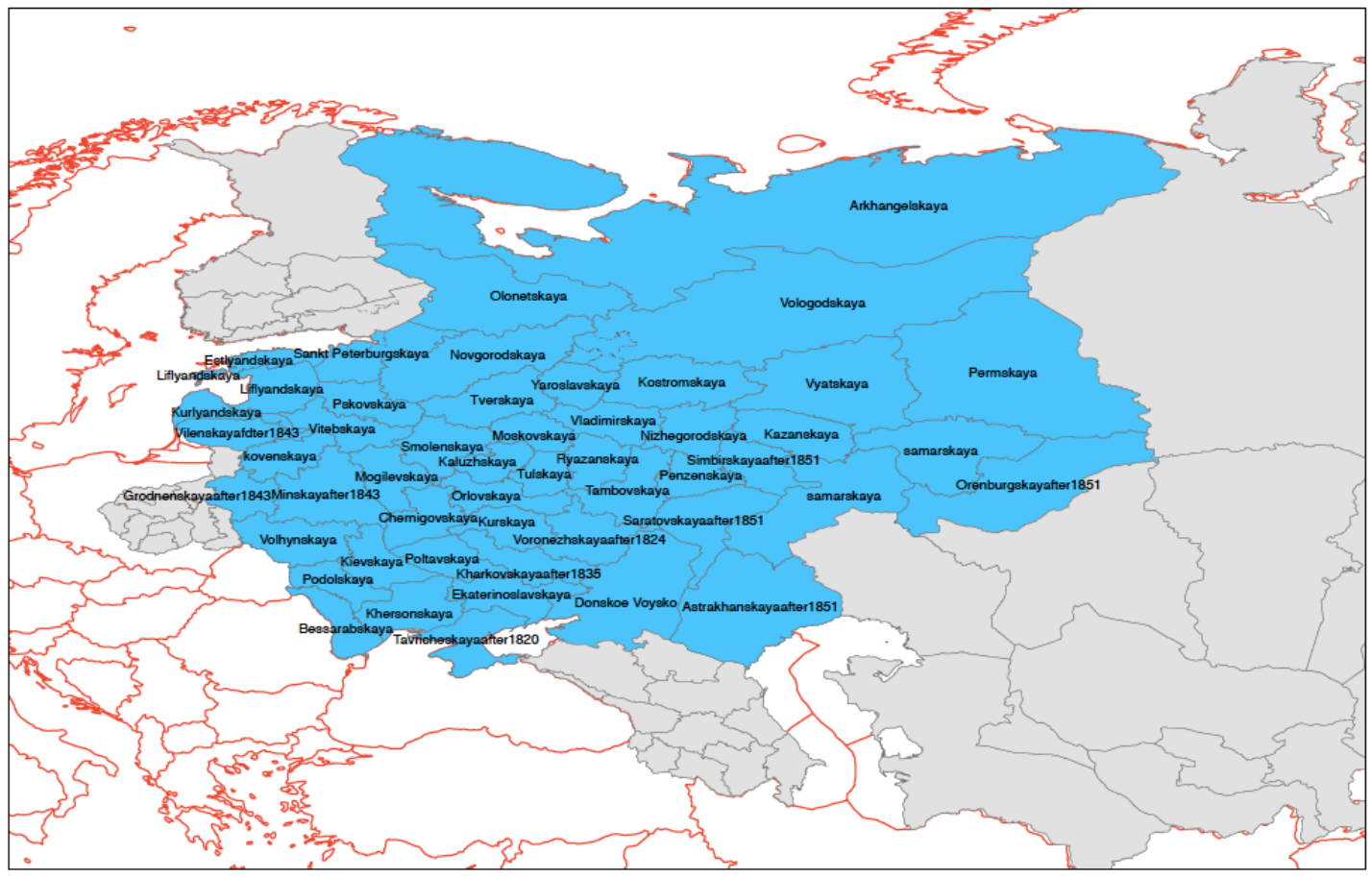

Note: European provinces are in blue; the rest provinces of the Russian Empire are in grey. Modern borders are in red. 
Figure 2. Geography of serfdom: private serfs in 1858 as a share of rural population

\section{Legend}

provinces

Share private serfs 1858

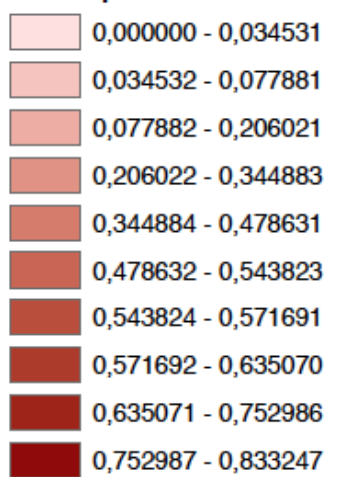

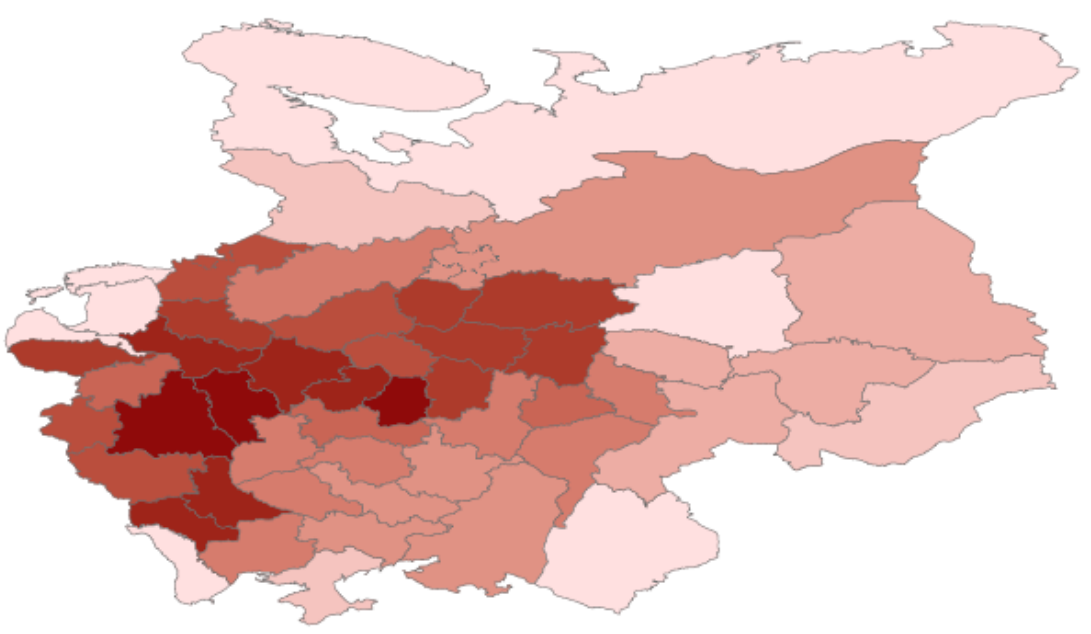


Figure 3. Geography of serfdom: state peasants (formally free) in 1858 as a share of rural population

\section{Legend}

\section{provinces}

Share state peasants 1858
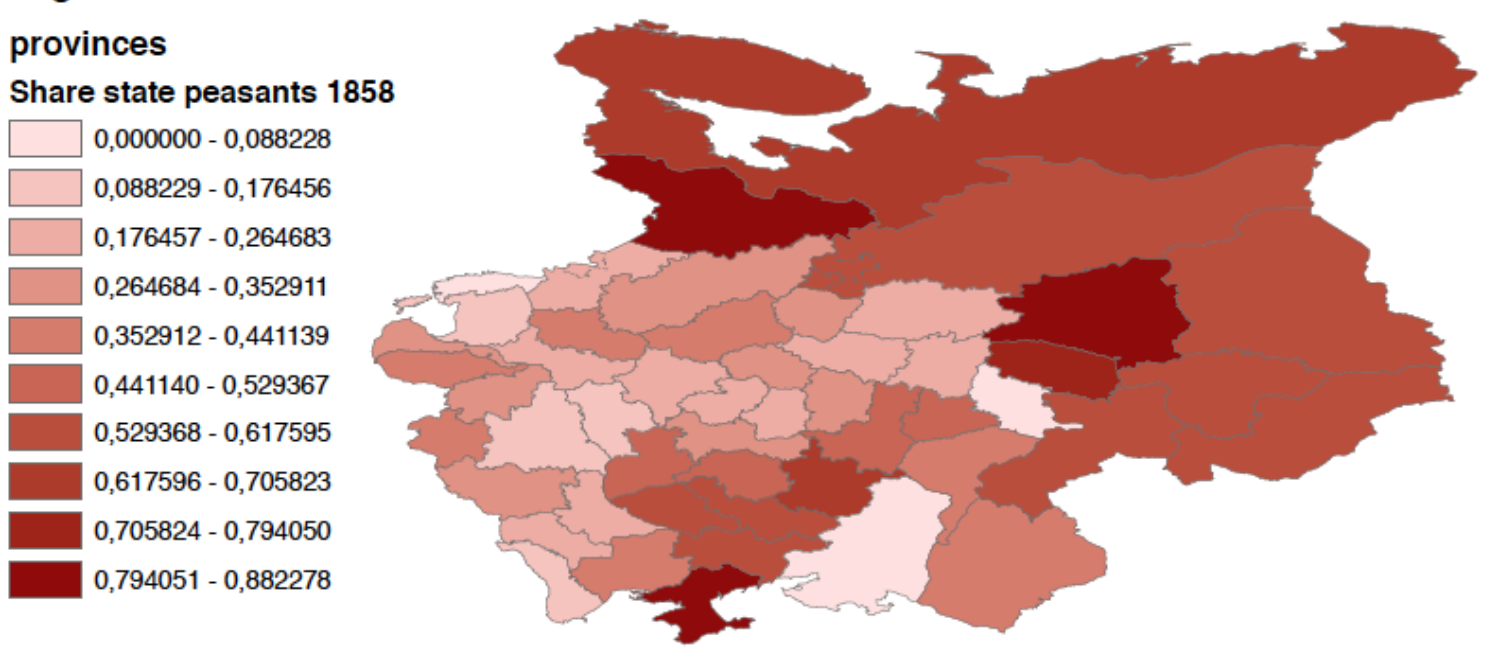

Figure 4. Geography of serfdom: free agricultural laborers in 1858 as a share of rural population

\section{Legend}

\section{provinces}

share free 1858

\begin{tabular}{|c|}
\hline $0,036558-0,038782$ \\
\hline $0,038783-0,041687$ \\
\hline $0,041688-0,042317$ \\
\hline $0,042318-0,044585$ \\
\hline $0,044586-0,050666$ \\
\hline $0,050667-0,051519$ \\
\hline $0,051520-0,057860$ \\
\hline $0,057861-0,067216$ \\
\hline $0,067217-0,093042$ \\
\hline $0,093043-0,099916$ \\
\hline $0,099917-0,128933$ \\
\hline $0,128934-0,189243$ \\
\hline $0,189244-0,556965$ \\
\hline $0,556966-0,825560$ \\
\hline $0,825561-0,985080$ \\
\hline
\end{tabular}

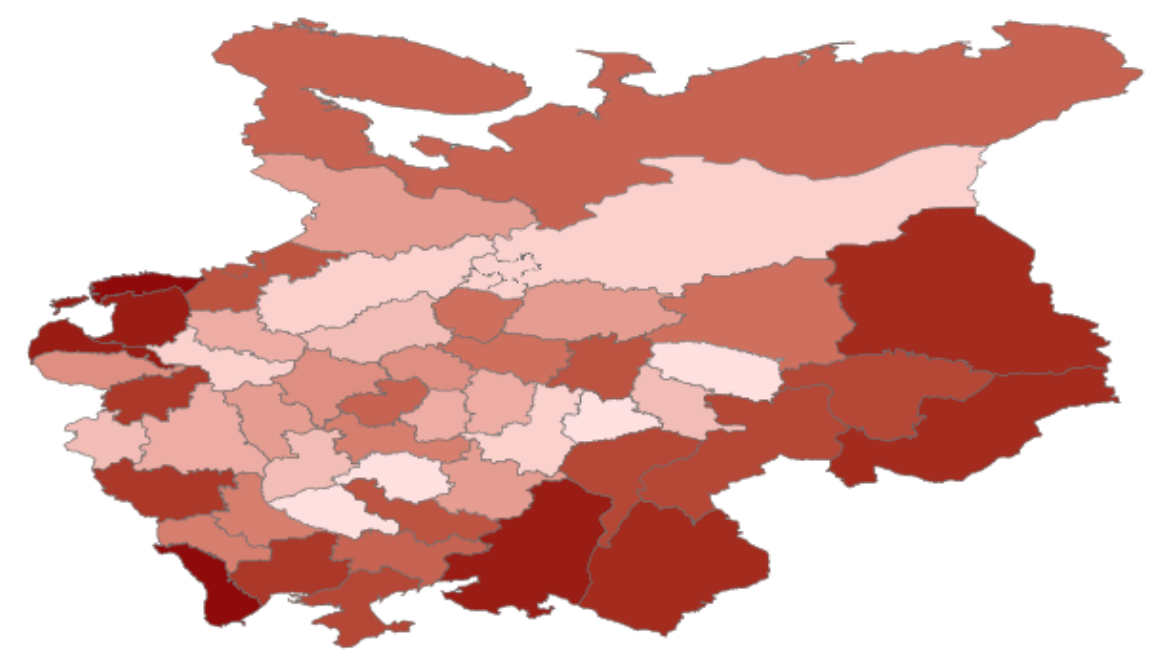


Figure 5. Geography of serfdom: corvee system in 1857 (the share of private serf on corvee)
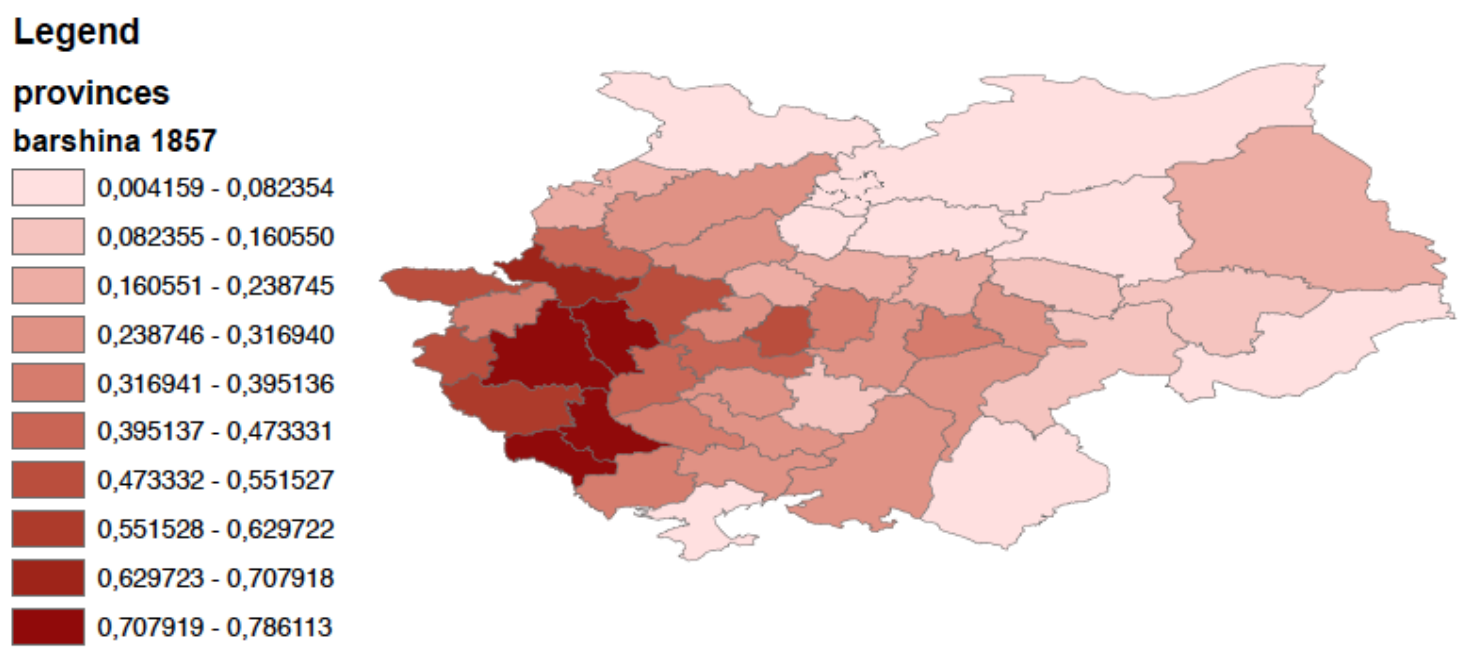

Figure 6. Geography of serfdom: quitrent in 1857 (the share of private serf under quitrent)

\section{Legend}

provinces

obrok 1857

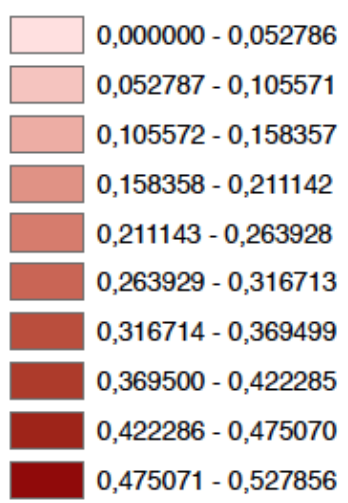

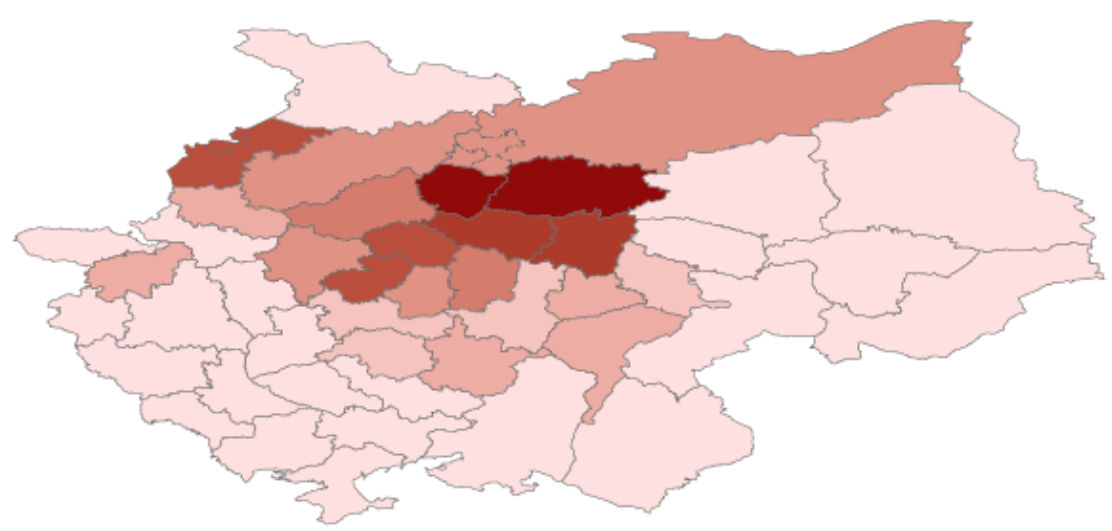


Figure 7. Time-varying effect of emancipation: grain productivity

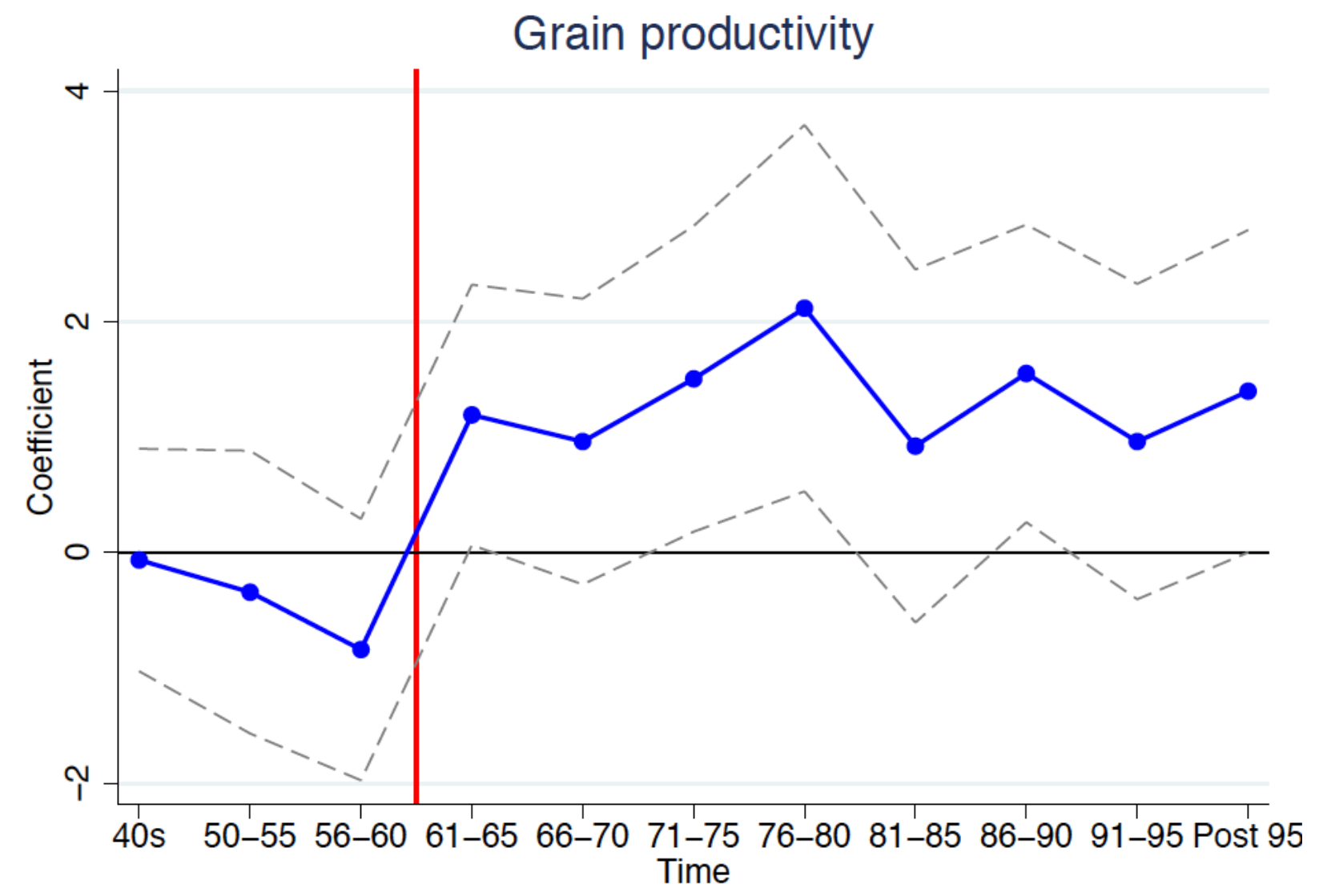

Note: Vertical red line marks the timing of the emancipation. 
Figure 8. Time-varying effect of emancipation: potato productivity

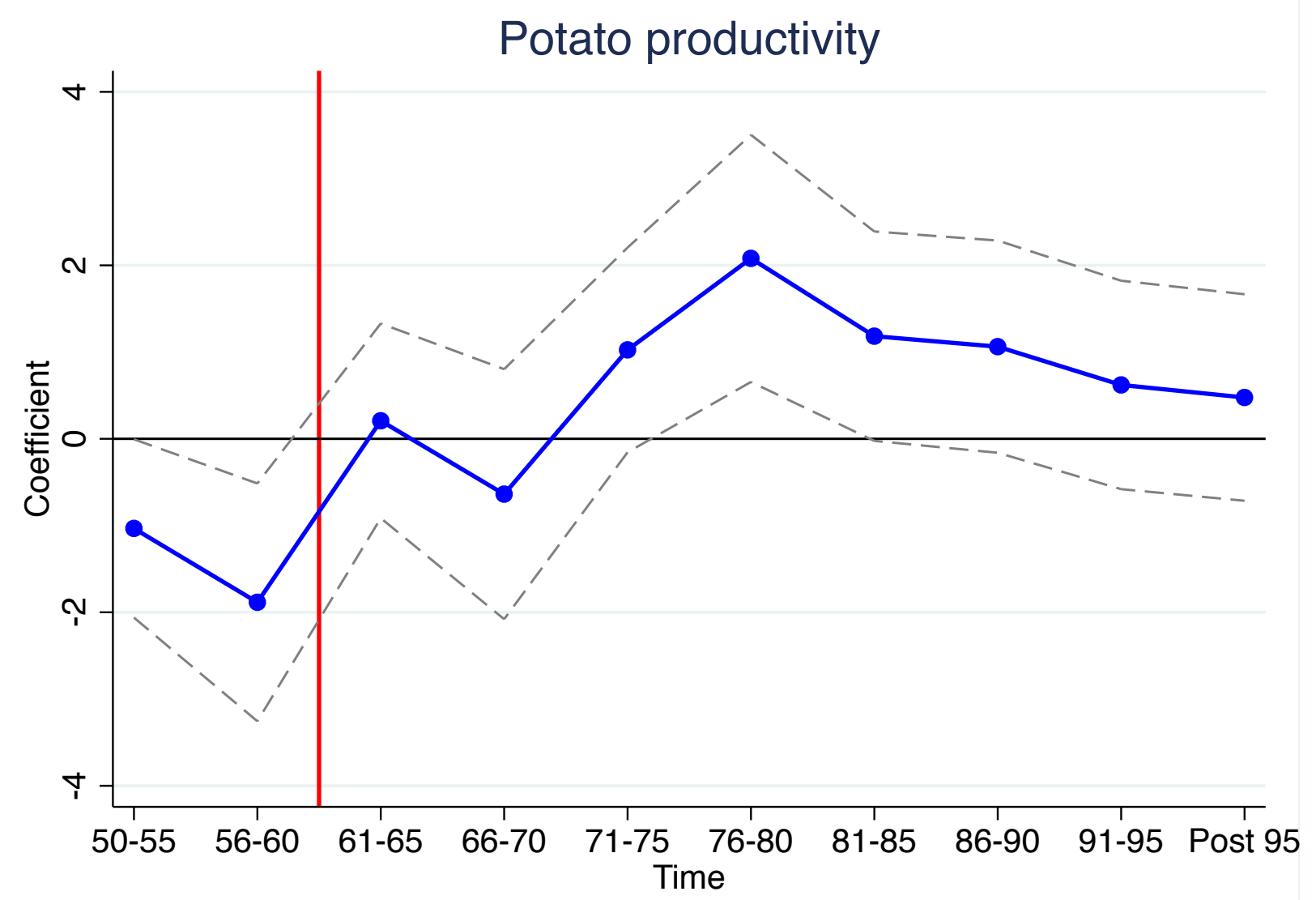

Note: Vertical red line marks the timing of the emancipation. 
Figure 9. Time-varying effect of emancipation: height

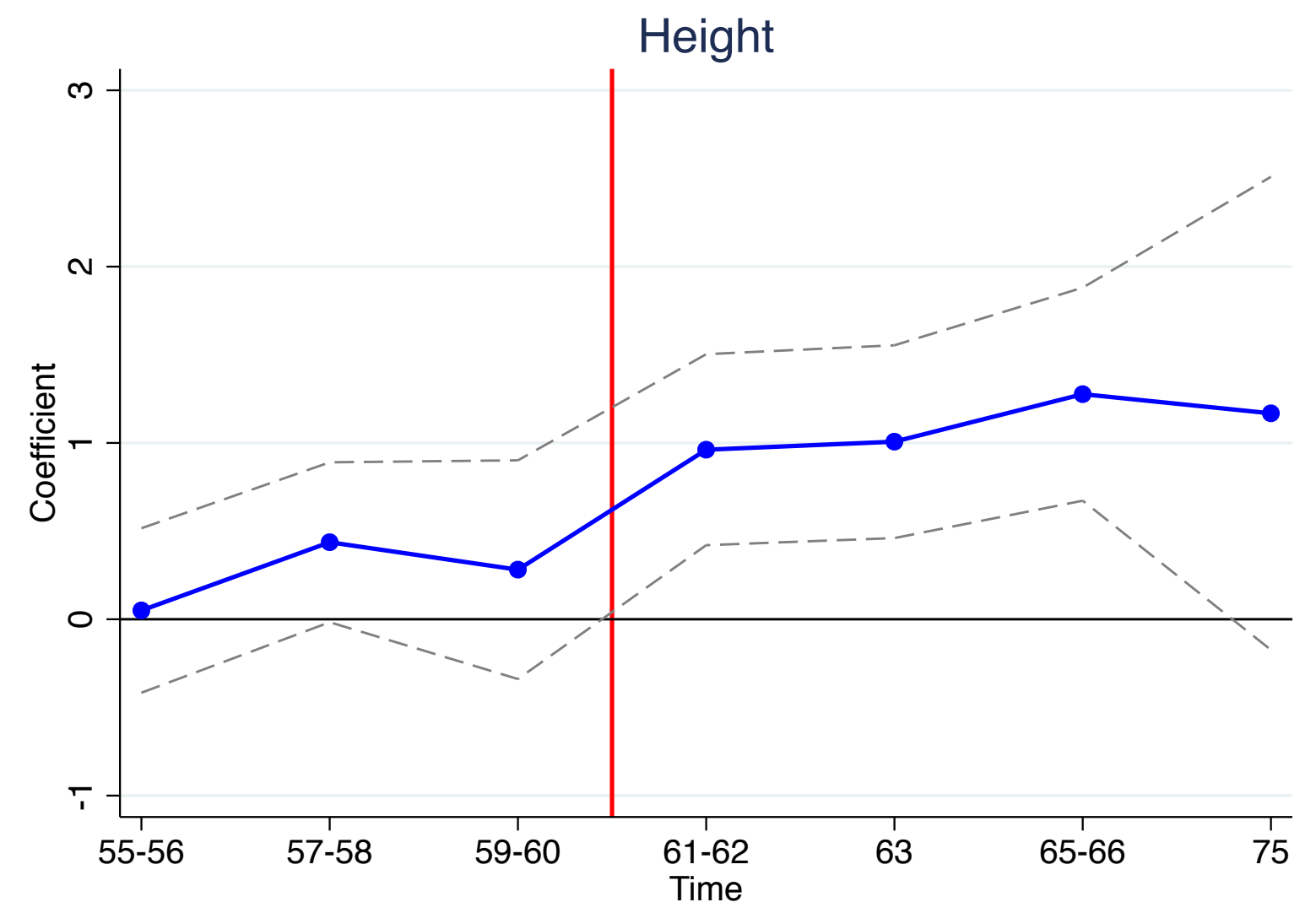

Note: Vertical red line marks the timing of the emancipation. 
Table 1. Summary statistics

Panel A. Distribution of rural population by status in 1858 (Source: 1858 police data)

\begin{tabular}{rccccc}
\hline & Obs & Mean & Std. Dev. & Min & Max \\
\hline Share of private serfs & 49 & 0.42 & 0.25 & 0 & 0.83 \\
Share of state peasants & 49 & 0.38 & 0.22 & 0 & 0.88 \\
Share of royal peasants & 49 & 0.04 & 0.08 & 0 & 0.47 \\
Share of free rural population & 49 & 0.16 & 0.24 & 0.04 & 0.99 \\
\hline
\end{tabular}

Panel B. Distribution of private serfs by type of obligations, estates' characteristics and the measures of land reform

\begin{tabular}{rccccc}
\hline & Obs & Mean & Std. Dev. & Min & Max \\
\hline $\begin{array}{r}\text { Share of private serfs on corvee in 1857 } \\
44\end{array}$ & 0.65 & 0.27 & 0.12 & 0.98 \\
Share of private serfs on quitrent in 1857 & 44 & 0.28 & 0.28 & 0.00 & 0.84 \\
Share of serf-servants in 1857 & 44 & 0.07 & 0.05 & 0.01 & 0.18 \\
$\begin{array}{r}\text { Land reform } \\
\text { She }\end{array}$ & 891 & 0.59 & 0.34 & 0 & 1 \\
$\begin{array}{r}\text { Share of private serfs, who launched the } \\
\text { land buyout operation) }\end{array}$ & & & & & \\
$\begin{array}{r}\text { Average number of serfs per landlord in } \\
\text { 1857 }\end{array}$ & 49 & 138.5 & 312.6 & 0 & 2232 \\
$\begin{array}{r}\text { Share of serfs with signed regulatory } \\
\text { charters by 1863 }\end{array}$ & 45 & 0.43 & 0.20 & 0.19 & 0.85 \\
$\begin{array}{r}\text { Share of repartition communes after the } \\
\text { emancipation } \\
\text { Land cuts }\end{array}$ & 50 & 0.71 & 0.41 & 0 & 1 \\
$\begin{array}{r}\text { (in percentage to peasants land before the } \\
\text { emancipation) }\end{array}$ & 43 & -0.065 & 0.20 & -42.4 & 41 \\
$\begin{array}{r}\text { Land plots per peasant household in 1877 } \\
\text { (in desyatinas) }\end{array}$ & 48 & 14.78 & 8.58 & 6.1 & 40.4 \\
\hline
\end{tabular}

$\underline{\text { Panel C. Development outcomes }}$

\begin{tabular}{rccccc}
\hline & Obs & Mean & Std. Dev. & Min & Max \\
\hline Grain productivity (yield to seed ratio) & 1606 & 3.93 & 1.32 & 0.59 & 12.3 \\
Potatoes productivity (yield to seed ratio) & 1487 & 4.36 & 1.25 & 0.01 & 18.84 \\
Cattle per capita (units) & 216 & 0.42 & 0.25 & 0.04 & 1.50 \\
Industrial output (mln current rubles) & 278 & 18.3 & 37.4 & 0.07 & 334 \\
Industrial workers (000) & 142 & 31.3 & 56 & 31 & 496.1 \\
Population (000) & 712 & 967.7 & 665.9 & 37.5 & 3981.9 \\
Births per capita & 531 & 0.047 & 0.008 & 0.02 & 0.12 \\
Deaths per capita & 531 & 0.035 & 0.008 & 0.02 & 0.12 \\
Height of draftees (centimeters) & 686 & 164.49 & 1.21 & 161.86 & 171.6 \\
\hline
\end{tabular}


Table 2. The effect of the abolition of serfdom on productivity in agriculture

\begin{tabular}{|c|c|c|c|c|c|}
\hline & \multicolumn{2}{|c|}{ Grain productivity } & \multicolumn{2}{|c|}{ Potato productivity } & $\begin{array}{c}(5) \\
\text { Cattle per } \\
\text { capita }\end{array}$ \\
\hline Share of private serfs $X$ & $1.03 * * *$ & $1.00 * *$ & $1.56^{* *}$ & $1.53 * *$ & $0.19 * * *$ \\
\hline Post-emancipation & {$[0.374]$} & {$[0.387]$} & {$[0.720]$} & [0.614] & [0.063] \\
\hline Share of state peasants X & $0.58 *$ & $0.74 * *$ & $1.56^{* *}$ & $1.53 * *$ & $0.28 * * *$ \\
\hline Post 1866 & {$[0.327]$} & {$[0.292]$} & {$[0.720]$} & {$[0.614]$} & {$[0.087]$} \\
\hline $\begin{array}{r}\text { Share of royal peasants X } \\
\text { Post } 1859 \\
\text { and land suitability X } \\
\text { Post-emancipation }\end{array}$ & Yes & Yes & Yes & Yes & Yes \\
\hline $\begin{array}{r}\text { Province-specific linear } \\
\text { trends }\end{array}$ & Yes & No & Yes & No & No \\
\hline $\begin{array}{r}\text { Region-specific linear } \\
\text { trends }\end{array}$ & No & Yes & No & Yes & Yes \\
\hline Time fixed effects & Yes & Yes & Yes & Yes & Yes \\
\hline Province fixed effects & Yes & Yes & Yes & Yes & Yes \\
\hline Observations & 1,584 & 1,584 & 1,392 & 1,392 & 203 \\
\hline R-squared & 0.525 & 0.504 & 0.327 & 0.303 & 0.923 \\
\hline
\end{tabular}

Notes: Standard errors are clustered by province separately before and after 1861 emancipation reform. Postemancipation is a dummy, which is switched on in 1861 in all provinces with the exception of the three Baltic provinces, where it is switched on in 1820 .

$* * *$ indicates $\mathrm{p}$-value $<0.01, * * \mathrm{p}$-value $<0.05,{ }^{*}$ p-value $<0.1$. 
Table 3. Disentangling the emancipation of serfs and the implementation of the land reform

(4) Grain productivity

Post-emancipation

$1.97 * * *$

$2.43 * * *$

$2.47 * * *$

$2.59 * * *$

$2.39 * * *$

Share of private serfs $\mathrm{X}$

[0.440]

[0.589]

[0.593]

[0.617]

[0.586]

$-1.02 * * *$

$-0.55^{*}$

$-0.62 *$

$-0.75^{*}$

Land reform

[0.289]

[0.284]

[0.339]

[0.448]

Share of private serfs $\mathrm{X}$

$0.23 * * * \quad 0.22 * * *$

Land reform $\mathrm{X}$

[0.061]

[0.066]

Land abundance

Land cuts X

Post-emancipation

[0.008]

Share of private serfs X
Land reform X
Repartition commune

\section{Share of state peasants X}

$1.03 * *$

$0.64 *$

0.67 *

$0.76^{* *}$

$0.63 *$

Post 1866

[0.354]

[0.368]

[0.371]

[0.378]

[0.366]

Share of royal peasants X Post 1859

Yes

Yes

Yes

Yes

Yes

emancipation

Province-specific linear trends

Yes

Yes

Yes

Yes

Yes

Yes

Yes

Province fixed effects

Yes

Yes

Yes

1,380

1,426

0.526

0.518

R-squared

0.516

0.506

Notes: The sample includes all provinces with the exception of the three Baltic provinces, which had no land reform. Standard errors are clustered by province separately before and after 1861 emancipation reform. Post-emancipation is a dummy, which is switched on in 1861 in all provinces with the exception of the three Baltic provinces, where it is switched on in 1820. Land reform is measured as the share of private serfs, who started the "land buy-out" operation at every point in time post-emancipation; it reaches 1 in all provinces by 1882 . Land abundance is measured as the size of the average peasant household land plot in 1877. Land cuts is ratio of land that peasants lost as a result of the reform (compared to the land they cultivated under serfdom) to the amount of land they received after the abolition of serfdom; with negative values mean that the peasants acquired more land than they used under serfdom.

*** indicates p-value $<0.01,{ }^{* *}$ p-value $<0.05,{ }^{*}$ p-value $<0.1$. 
Table 4. Differential effects in the abolition of serfdom, depending of its organizational structure: Corvee vs. quitrent in large and small estates and the implicit contracts

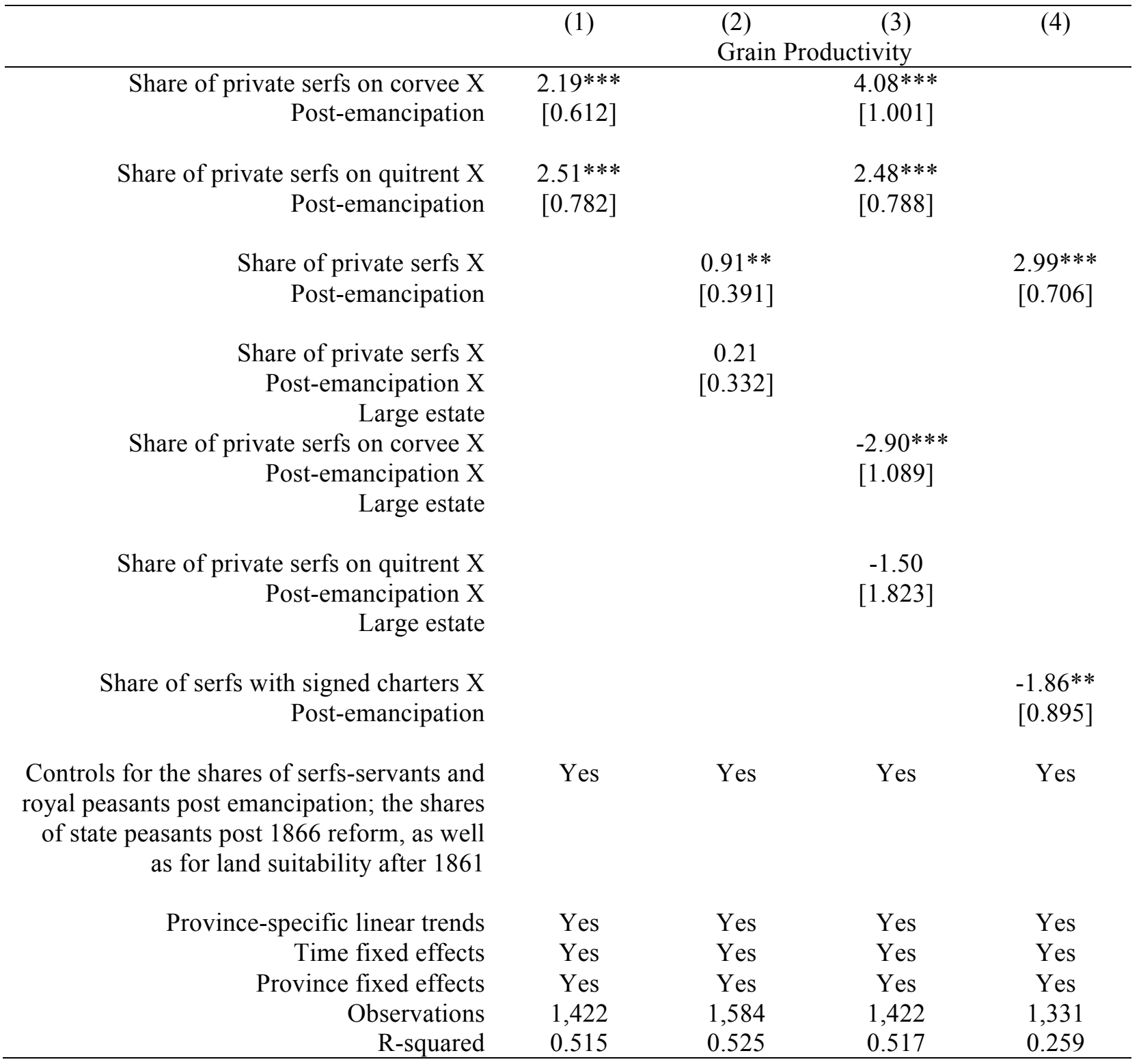

Notes: Standard errors are clustered by province separately before and after 1861 emancipation reform. Postemancipation is a dummy, which is switched on in 1861 in all provinces with the exception of the three Baltic provinces, where it is switched on in 1820. Share of serfs with signed charters is a proxy for the presence of an implicit contract between the landlords and peasants before emancipation. In column 4 we also include a control for the differential effect of the size of the estate on the emancipation of serf-servants.

$* * *$ indicates p-value $<0.01, * *$ p-value $<0.05, *$ p-value $<0.1$. 
Table 5. The abolition of serfdom and the peasant living standards: draftees' height

\begin{tabular}{|c|c|c|c|c|}
\hline \multirow[b]{3}{*}{ Sample: } & (1) & (2) & (3) & (4) \\
\hline & \multicolumn{4}{|c|}{ Draftees' height } \\
\hline & $\begin{array}{c}\text { Full } \\
\text { sample }\end{array}$ & $\begin{array}{c}\text { Born in } \\
1853 \text { and } \\
\text { after } 1860\end{array}$ & $\begin{array}{c}\text { Full } \\
\text { sample }\end{array}$ & $\begin{array}{c}\text { Born in } \\
1853 \text { and } \\
\text { after } 1860\end{array}$ \\
\hline Share of private serfs $X$ & $0.80 * * *$ & $1.21 * * *$ & & \\
\hline Post-emancipation & {$[0.195]$} & \multicolumn{2}{|l|}{$[0.440]$} & \\
\hline \multirow{2}{*}{\multicolumn{2}{|c|}{$\begin{array}{r}\text { Share of private serfs on corvee X } \\
\text { Post-emancipation }\end{array}$}} & \multirow{2}{*}{\multicolumn{2}{|c|}{$\begin{array}{l}0.90 * * * \\
{[0.269]}\end{array}$}} & $1.59 * *$ \\
\hline & & & & {$[0.610]$} \\
\hline \multirow{2}{*}{\multicolumn{2}{|c|}{$\begin{array}{r}\text { Share of private serfs on quitrent } X \\
\text { Post-emancipation }\end{array}$}} & & \multirow{2}{*}{$\begin{array}{c}0.38 \\
{[0.409]}\end{array}$} & \multirow{2}{*}{$\begin{array}{c}0.27 \\
{[0.867]}\end{array}$} \\
\hline & & & & \\
\hline \multirow{2}{*}{$\begin{array}{r}\text { Share of state peasants X } \\
\text { Post } 1866\end{array}$} & 0.26 & -0.02 & 0.06 & \multirow{2}{*}{$\begin{array}{c}-0.20 \\
{[0.447]}\end{array}$} \\
\hline & {$[0.413]$} & {$[0.463]$} & {$[0.416]$} & \\
\hline Share of serfs-servants $X$ & Yes & Yes & Yes & Yes \\
\hline \multirow{2}{*}{\multicolumn{5}{|c|}{$\begin{array}{r}\text { Post-emancipation; } \\
\text { Share of royal peasants X }\end{array}$}} \\
\hline & & & & \\
\hline \multicolumn{5}{|l|}{ Post1859 } \\
\hline Region-specific linear trends & Yes & Yes & Yes & Yes \\
\hline Time fixed effects & Yes & Yes & Yes & Yes \\
\hline Province fixed effects & Yes & Yes & Yes & Yes \\
\hline Observations & 644 & 322 & 616 & 264 \\
\hline R-squared & 0.876 & 0.907 & 0.881 & 0.914 \\
\hline
\end{tabular}

Notes: Standard errors are clustered by province separately before and after 1861 emancipation reform. Postemancipation is a dummy, which is switched on in 1861 in all provinces with the exception of the three Baltic provinces, where it is switched on in $1820 .{ }^{* * *}$ indicates $\mathrm{p}$-value $<0.01,{ }^{* *}$ p-value $<0.05,{ }^{*}$ p-value $<0.1$. 
Table 6. The abolition of serfdom and the peasant living standards: demographics

\begin{tabular}{rccc}
\hline & $(1)$ & $(2)$ & $(3)$ \\
& Deaths per capita & Births per capita & Ln (population) \\
\hline $\begin{array}{r}\text { Share of private serfs X } \\
\text { Post-emancipation }\end{array}$ & $-0.0056^{* *}$ & 0.0027 & $0.0597^{*}$ \\
& {$[0.002]$} & {$[0.006]$} & {$[0.035]$} \\
Share of state peasants X & -0.0027 & -0.0013 & $-0.1818^{* * *}$ \\
Post 1866 & {$[0.003]$} & {$[0.007]$} & {$[0.067]$} \\
& & & \\
Phare of royal peasants X & Yes & Yes & Yes \\
Post1859 & & & Yes \\
Region-specific linear trends & Yes & Yes & Yes \\
Time fixed effects & Yes & Yes & Yes \\
Province fixed effects & Yes & Yes & 712 \\
Observations & 501 & 501 & 0.978 \\
\hline
\end{tabular}

Notes: Standard errors are clustered by province separately before and after 1861 emancipation reform. Postemancipation is a dummy, which is switched on in 1861 in all provinces with the exception of the three Baltic provinces, where it is switched on in 1820 . ${ }^{* * *}$ indicates $\mathrm{p}$-value $<0.01, * *$ p-value $<0.05, * \mathrm{p}$-value $<0.1$. 
Table 7. The abolition of serfdom and the industrial development

(1)

(2)

Ln (industrial output)

Ln (industrial workers)

Share of private serfs $X$

Post-emancipation

Share of state peasants $\mathrm{X}$

Post 1866
$1.14 * * *$

[0.378]

$1.03^{*}$

[0.529]

Yes

Yes

Yes

Yes

263

0.952

\subsection{9 ***}

[0.417]

$-0.38$

[0.905]

Yes

Yes

Yes

Yes

133

0.969

Notes: Standard errors are clustered by province separately before and after 1861 emancipation reform. Postemancipation is a dummy, which is switched on in 1861 in all provinces with the exception of the three Baltic provinces, where it is switched on in 1820 . $* * *$ indicates p-value $<0.01, * *$ p-value $<0.05, *$ p-value $<0.1$. 


\section{Appendix}

Figure A1. Geography of serfdom: share of private serfs in 1858 and the distance to Moscow

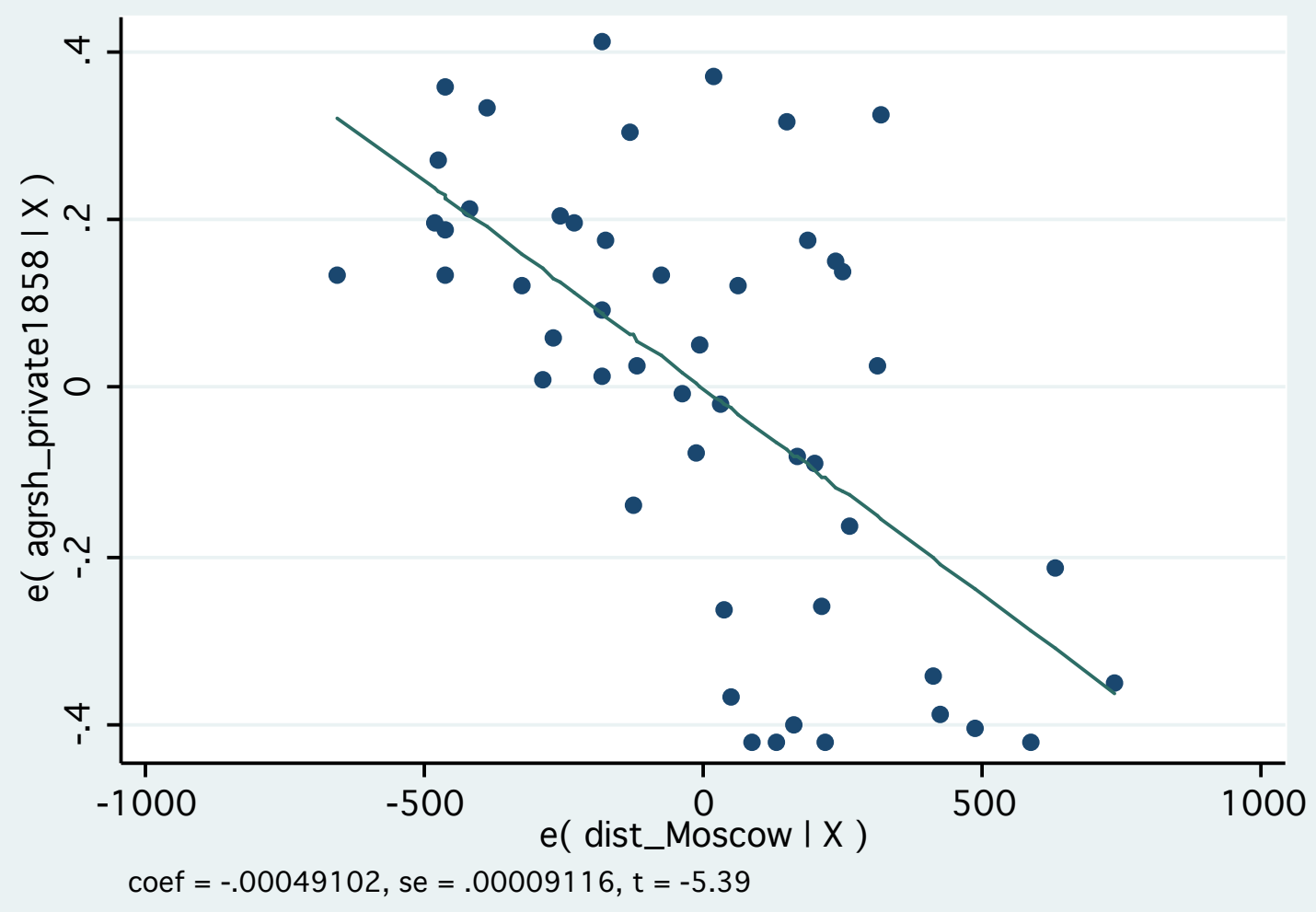


Table A1. Data sources.

\begin{tabular}{|c|c|c|}
\hline \multicolumn{3}{|c|}{ Outcome variables } \\
\hline Variable: & Years: & Source: \\
\hline \multirow{6}{*}{ Grain yield } & 1800 s- 1850 s by decade & Koval'chenko (1959) \\
\hline & 1795 and 1858 & Kessler and Markevich (2014) \\
\hline & $1864-1866$ by year & Obruchev (1871) \\
\hline & $1870-1876$ by year & Materialy ... (1880) \\
\hline & $1883-1887$ by year & TsSK MVD (1888) \\
\hline & $1888-1900$ by year & Urozhaj v ... (1889-1901) \\
\hline \multirow{6}{*}{ Potato yield } & $\begin{array}{l}1800 \mathrm{~s}-1820 \mathrm{~s} \text { and } 1840- \\
1850 \mathrm{~s} \text { by decade }\end{array}$ & Koval'chenko (1959) \\
\hline & 1858 & Kessler and Markevich (2014) \\
\hline & $1864-1866$ by year & Obruchev (1871) \\
\hline & $1870-1876$ by year & Materialy ... (1880) \\
\hline & $1883-1887$ by year & TsSK MVD (1888) \\
\hline & $1888-1900$ by year & Urozaj v ...(1889-1901) \\
\hline \multirow{5}{*}{ Cattle } & 1840 & Vilson (1857) \\
\hline & 1856 & Statisticheckie ... (1858) \\
\hline & 1858 & Kessler and Markevich (2014) \\
\hline & 1870 & Statisticheckii ... (1875) \\
\hline & 1883 & Statisticheckii ... (1886) \\
\hline \multirow{6}{*}{ Population } & 1800s-1850s by decade & Kabuzan (1971) \\
\hline & 1849 & Statisticheckie ... (1852) \\
\hline & 1856 & Statisticheckie ... (1858) \\
\hline & 1858 & Kessler and Markevich (2014) \\
\hline & 1870 & Statisticheckii ... (1875) \\
\hline & 1883 & Statisticheckii ... (1886) \\
\hline \multirow{4}{*}{ Height of draftees } & $1853-1862$ by year & Vseobshchaya ... (1886) \\
\hline & 1863 & Sbornik ... (1887) \\
\hline & $1865-1866$ by year & Sbornik ... (1890) \\
\hline & 1875 & Sbornik ... (1897) \\
\hline \multirow[t]{6}{*}{ Industrial output } & 1849 & Statisticheckie ... (1852) \\
\hline & 1856 & Statisticheckie ... (1858) \\
\hline & 1858 & Kessler and Markevich (2014) \\
\hline & 1882 & Sbornik ... (1884) \\
\hline & 1884 & Statisticheckii ... (1887) \\
\hline & 1897 & Kessler and Markevich (2014) \\
\hline \multirow[t]{3}{*}{ Industrial employment } & 1847 & Statisticheckie ... (1849) \\
\hline & 1882 & Sbornik ... (1884) \\
\hline & 1897 & Kessler and Markevich (2014) \\
\hline \multirow[t]{9}{*}{ Number of births } & 1856 & Statisticheckie ... (1858) \\
\hline & 1858 & Kessler and Markevich (2014) \\
\hline & 1867 & Statisticheckii ... (1872) \\
\hline & $1868-1870$ by year & Statisticheckii ... $(1877,1879)$ \\
\hline & 1875 & Statisticheckii ... (1883a) \\
\hline & 1880 & Statisticheckii ... (1883b) \\
\hline & 1885 & Statisticheckii ... (1890) \\
\hline & 1890 & Statisticheckii ... (1895) \\
\hline & 1896 & Statisticheckii ... (1898) \\
\hline
\end{tabular}


Table A1 continued

\begin{tabular}{|c|c|c|}
\hline \multirow[t]{9}{*}{ Number of deaths } & 1856 & Statisticheckie ... (1858) \\
\hline & 1858 & Kessler and Markevich (2014) \\
\hline & 1867 & Statisticheckii ... (1872) \\
\hline & $1868-1870$ by year & Statisticheckii ... $(1877,1879)$ \\
\hline & 1875 & Statisticheckii ... (1883a) \\
\hline & 1880 & Statisticheckii ... (1883b) \\
\hline & 1885 & Statisticheckii ... (1890) \\
\hline & 1890 & Statisticheckii ... (1895) \\
\hline & 1896 & Statisticheckii ... (1898) \\
\hline \multicolumn{3}{|c|}{ Explanatory variables } \\
\hline Variable: & Years: & Source: \\
\hline \multirow{2}{*}{$\begin{array}{l}\text { Distribution of rural } \\
\text { population by status }\end{array}$} & 1858 & Bushen (1863) \\
\hline & 1857 & Kabuzan (1971) \\
\hline $\begin{array}{l}\text { Private serfs obligations: } \\
\text { corvee and quitrent }\end{array}$ & 1857 & Skrebitskii (1862-1866) \\
\hline Redemption payments & $1862-1876$ by year & Vilson (1878) \\
\hline $\begin{array}{l}\text { Signed and unsigned } \\
\text { regulatory charters }\end{array}$ & 1863 & Vilson (1878) \\
\hline Serfs per estate & 1857 & Troinitskii (1858) \\
\hline $\begin{array}{l}\text { Gentry debts and } \\
\text { mortgages }\end{array}$ & 1855 & Skrebitskii (1862-1866) \\
\hline $\begin{array}{l}\text { Share of repartition } \\
\text { communes after the } \\
\text { emancipation }\end{array}$ & 1905 & Rossiya 1913 god ... (1995) \\
\hline $\begin{array}{l}\text { Land cuts (in percentage } \\
\text { to peasants land before } \\
\text { the emancipation) }\end{array}$ & 1863 & Zaionchkovskii (1960) \\
\hline $\begin{array}{l}\text { Land allotments per } \\
\text { household and land } \\
\text { statistics }\end{array}$ & 1877 & Statistika (1905) \\
\hline Railways density & 1897 & Kessler and Markevich (2014) \\
\hline
\end{tabular}


Table A2. Dynamics of the results of the abolition of serfdom

\begin{tabular}{|c|c|c|c|}
\hline & $\begin{array}{c}\text { (1) } \\
\text { Grain } \\
\text { productivity }\end{array}$ & $\begin{array}{c}(2) \\
\text { Potato } \\
\text { productivity }\end{array}$ & $\begin{array}{c}(3) \\
\text { Draftees } \\
\text { height }\end{array}$ \\
\hline Share of private serfs in $1840 \mathrm{~s}$ & $\begin{array}{c}-0.07 \\
{[0.588]}\end{array}$ & & \\
\hline Share of private serfs in $1850-1855$ & $\begin{array}{c}-0.34 \\
{[0.747]}\end{array}$ & $\begin{array}{c}-1.03 \\
{[0.627]}\end{array}$ & \\
\hline Share of private serfs in $1856-1860$ & $\begin{array}{c}-0.84 \\
{[0.691]}\end{array}$ & $\begin{array}{r}-1.89 * * \\
{[0.836]}\end{array}$ & \\
\hline Share of private serfs in $1861-1865$ & $\begin{array}{c}1.19^{*} \\
{[0.688]}\end{array}$ & $\begin{array}{c}0.21 \\
{[0.684]}\end{array}$ & \\
\hline Share of private serfs in $1866-1870$ & $\begin{array}{c}0.96 \\
{[0.755]}\end{array}$ & $\begin{array}{c}-0.64 \\
{[0.878]}\end{array}$ & \\
\hline Share of private serfs in $1871-1875$ & $\begin{array}{c}1.50^{*} \\
{[0.808]}\end{array}$ & $\begin{array}{c}1.02 \\
{[0.719]}\end{array}$ & \\
\hline Share of private serfs in $1876-1880$ & $\begin{array}{l}2.12 * * \\
{[0.968]}\end{array}$ & $\begin{array}{l}2.08 * * \\
{[0.869]}\end{array}$ & \\
\hline Share of private serfs in $1881-1885$ & $\begin{array}{c}0.92 \\
{[0.933]}\end{array}$ & $\begin{array}{c}1.18 \\
{[0.736]}\end{array}$ & \\
\hline Share of private serfs in $1886-1890$ & $\begin{array}{c}1.55^{*} \\
{[0.786]}\end{array}$ & $\begin{array}{c}1.06 \\
{[0.746]}\end{array}$ & \\
\hline Share of private serfs in 1891-1895 & $\begin{array}{c}0.96 \\
{[0.833]}\end{array}$ & $\begin{array}{c}0.62 \\
{[0.733]}\end{array}$ & \\
\hline Share of private serfs after 1895 & $\begin{array}{c}1.40 \\
{[0.852]}\end{array}$ & $\begin{array}{c}0.48 \\
{[0.726]}\end{array}$ & \\
\hline Share of private serfs in $1855-1856$ & & & $\begin{array}{c}0.05 \\
{[0.285]}\end{array}$ \\
\hline Share of private serfs in $1857-1858$ & & & $\begin{array}{c}0.44 \\
{[0.279]}\end{array}$ \\
\hline Share of private serfs in $1859-1860$ & & & $\begin{array}{c}0.29 \\
{[0.375]}\end{array}$ \\
\hline Share of private serfs in $1861-1862$ & & & $\begin{array}{l}0.98^{* * *} \\
{[0.333]}\end{array}$ \\
\hline Share of private serfs in 1863 & & & $\begin{array}{l}1.00^{* * *} \\
{[0.339]}\end{array}$ \\
\hline Share of private serfs in $1865-1866$ & & & $\begin{array}{l}1.25^{* * *} \\
{[0.389]}\end{array}$ \\
\hline Share of private serfs in 1875 & & & $\begin{array}{c}1.13 \\
{[0.851]}\end{array}$ \\
\hline Share of state peasants X Post 1866 & $\begin{array}{l}1.21 * * \\
{[0.535]}\end{array}$ & $\begin{array}{c}0.36 \\
{[0.635]}\end{array}$ & $\begin{array}{c}0.30 \\
{[0.469]}\end{array}$ \\
\hline $\begin{array}{l}\text { All baseline controls and regions- } \\
\text { specific trends }\end{array}$ & Yes & Yes & Yes \\
\hline Observations & 1,488 & 1,392 & 644 \\
\hline R-squared & 0.486 & 0.313 & 0.877 \\
\hline
\end{tabular}

Notes: Standard errors are clustered by province separately before and after 1861 emancipation reform. $* * *$ indicates p-value $<0.01,{ }^{* *}$ p-value $<0.05,{ }^{*}$ p-value $<0.1$. 


\section{References for sources in Table A1}

Bushen A., (1863). Statisticheskie tablitsi Rossijskoj imperii. Nalichnoe naselenie imperii za 1858. [Statistical tables of the Russian empire. Population in 1858]. Saint-Petersburg, 1858 .

Kessler, Gijs and Andrei Markevich, (2014). Electronic Repository of Russian Historical Statistics, 18th - 21st centuries, http://ristat.org/

Kabuzan V.M., (1971). Izmenenie v razmeshchenii naseleniya Rossii v 18 -pervoi polovine 19 $v v$. [Changes in population geography in $18^{\text {th }}$ - first half of $19^{\text {th }} \mathrm{Cc}$.]. Moscow.

Koval'chenko I.D., (1959). Dinamika urovnya zemledelcheskogo proizvodstava v pervoi polovine 19 C. [Dynamic of agricultural output in the first half of $19^{\text {th }}$ C.], History of the USSR, 1959 (1).

Materialy po statistike khlebnoj proizvoditelnosti v Evropejskoi Rossii za pyatiletnii period s 1870-1874 [Statistical data on grain production in European Russia in 1870-1874]. SaintPetersburg (1880).

Obruchev N.N., (1871). Voenno-statisticheskii sbornik. [Military-statistical volume]. Issue 4. Russia.

Rossiya 1913 god. Statistiko-dokumentalnij spravochnik. Saint_Petersburg: BLITs. (1994).

Sbornik svedenii po Evropejskoj Rossii za 1882 [Statistical volume on European Russia in 1882] Saint-Petersburg, 1884.

Sbornik svedenii po Rossii za 1884-1885 [Statistical volume on Russia in 1884-1885] SaintPetersburg, 1887.

Sbornik svedenii po Rossii, 1890 [Statistical volume on Russia in 1890] Saint-Petersburg, 1890.

Sbornik svedenii po Rossii, 1896 [Statistical volume on Russia in 1896] Saint-Petersburg, 1897.

Skrebitskii A. Krestyanskoe delo v tzarstvovanie imperatora Aleksandra II: materiali dlya istorii osvobozhdeniya krestyan: guberntskie komiteti, ikh deputati I redaktsionnie komissii v krestyanskom dele. [Peasants question during the reign of Alexander II: materials] Vol. 14. Bonn-na-Reine, 1862-1866.

Statisticheskie tablitsi o sostiyanii gorodov Rossijskoj imperii za 1847 [Statistical tables on cities of Russian empire for 1849]. Saint-Petersburg, 1849.

Statisticheskie tablitsi sostavlennie v statisticheskom otdelenii soveta MVD po svedeniyam za 1849 [Statistical tables constructed by statistical agency of the Ministry of internal affairs with data for 1849]. Saint-Petersburg, 1852.

Statisticheskie tablitsi Rossijskoj imperii za 1856 [Statistical tables of the Russian empire in 1858]. Saint-Petersburg, 1858

Statisticheskii vremennik Rossijskoi imperii [Statistical periodical volume of Russian empire]. Series 2. Issue 8. Saint-Petersburg, 1872.

Statisticheskii vremennik Rossijskoi imperii [Statistical periodical volume of Russian empire]. Series 2. Issue 10. Saint-Petersburg, 1875.

Statisticheskii vremennik Rossijskoi imperii [Statistical periodical volume of Russian empire]. Series 2. Issue 19. Saint-Petersburg, 1877.

Statisticheskii vremennik Rossijskoi imperii [Statistical periodical volume of Russian empire]. Series 2. Issue 14. Saint-Petersburg, 1879.

Statisticheskii vremennik Rossijskoi imperii [Statistical periodical volume of Russian empire]. Series 1. Issue 22. Saint-Petersburg, 1883a. 
Statisticheskii vremennik Rossijskoi imperii [Statistical periodical volume of Russian empire]. Series 3. Issue 7. Saint-Petersburg, 1883 b.

Statisticheskii vremennik Rossijskoi imperii [Statistical periodical volume of Russian empire]. Series 2. Issue 11. Saint-Petersburg, 1885.

Statisticheskii vremennik Rossijskoi imperii [Statistical periodical volume of Russian empire]. Series 3. Issue 8. Saint-Petersburg, 1886.

Statisticheskii vremennik Rossijskoi imperii [Statistical periodical volume of Russian empire]. Series 1. Issue 22. Saint-Petersburg, 1895.

Statisticheskii vremennik Rossijskoi imperii [Statistical periodical volume of Russian empire]. Series 1. Issue 30. Saint-Petersburg, 1898.

Statistika zemlevladeniya 1905: Svod dannikh po 50 guberniyam Evropejskoj Rossii. SaintPetersburg, 1905.

TsSK MVD (Central Statistical committee of the Ministry of Internal Affairs) (1888). Statistika Rossijskoj imperii. Srednii urojai v Evropejskoi Rossii za pyatiletie 1883 - 1887. [Statistics of Russian empire. Average harvest in European Russia during 1884-1887]. Saint-Petersburg.

Troinitskii A. (1858). "O chisel krepostnikh ludej v Rossii” [On number of serfs in Russia], Journal of the Ministry of Internal Affairs of the Russian Empire 30(III), Pp. 1-36.

Urozhaj v ... godu [Harvest in ... year]. Annual volumes. Saint-Petersburg, 1889-1901.

Vilson I. (1857). Obyasnenie k khozyastvennomu atlasu Evropejskoi Rossii [Explanations for economic atlas of European Russia]. $3^{\text {rd }}$ edition. Saint-Petersburg.

Vseobshchay voinskaya povinnost v Rossijskoi imperii za pervoe desyatiletie, 1874-1883 [Military duty in the first decade, 1874-1883]. Saint-Petersburg, 1886.

Zajnchkovskij P.A. (1968). Otmena krepostnogo prava v Rossii [Abolishment of Serfdom in Russia]. Moscow: Nauka. 


\section{The definition of the 15 regions}

1. North: Arkhangelsk, Vologoda and Olonets provinces;

2. North-West: Novgorod and Pskov provinces;

3. Baltic: Estlyandiya, Liflyandiya and Kurlyandiya provinces;

4. West: Smolensk, Vitebsk and Mogilev provinces;

5. Belorussia and Lithonia: Minsk, Grodno, Vil'no and Kovno provinces;

6. Central Industrial Region: Vladimir, Nizhnij Novgorod, Kostroma, Yaroslavl' and Tver' provinces;

7. Central Black Earth Region: Kaluga, Tula, Ryasan', Orel, Tambov, Kursk, Voronezh provinces;

8. Middle Volga: Kazan', Penza and Simbirsk provinces;

9. Left Bank Ukraine: Chernigov, Poltava and Khar'kov provinces;

10. Right Bank Ukraine: Kiev, Podoliya, Volyn' and Bessarabiya provinces;

11. South: Kherson, Tavrida, Ekaterinoslav, Don and Stavropol' provinces;

12. Low Volga: Saratov and Samara provinces;

13. Astrakhan': Astakhan' province;

14. Urals: Orenburg, Vyatka and Per'm provinces;

15. Capitals: Moskovskaya and Saint-Peterburgskaya. 